NBER WORKING PAPER SERIES

\title{
THE ENVIRONMENTAL KUZNETS CURVE: EXPLORING A FRESH SPECIFICATION
}

\author{
David F. Bradford \\ Rebecca Schlieckert \\ Stephen H. Shore \\ Working Paper 8001 \\ http://www.nber.org/papers/w8001

\section{NATIONAL BUREAU OF ECONOMIC RESEARCH \\ 1050 Massachusetts Avenue} \\ Cambridge, MA 02138 \\ November 2000
}

We would like to thank Princeton's Woodrow Wilson School and Center for Economic Policy Studies for financial support, Gene Grossman and Alan Krueger for their extraordinary generosity in supplying us with the data and computer programs used in their path-breaking work and for patiently answering queries about it, and Lawrence Goulder and other participants at an NBER Public Economics program meeting for comments. Bradford also thanks the Center for Economic Studies of the University of Munich for hospitality. The views expressed in this paper are those of the authors and not necessarily those of the National Bureau of Economic Research.

(C) 2000 by David F. Bradford, Rebecca Schlieckert, and Stephen H. Shore. All rights reserved. Short sections of text, not to exceed two paragraphs, may be quoted without explicit permission provided that full credit, including $\mathbb{C}$ notice, is given to the source. 
The Environmental Kuznets Curve: Exploring A Fresh Specification

David F. Bradford, Rebecca Schlieckert, and Stephen H. Shore

NBER Working Paper No. 8001

November 2000

JEL No. O0, C4, N5

\begin{abstract}
Using a new specification, we reanalyze the data on worldwide environmental quality investigated by Gene Grossman and Alan Krueger in a well-known paper on the environmental Kuznets curve (which postulates an inverse $U$ shaped relationship between income level and pollution). The new specification enables us to draw conclusions from fixed effects estimation. In general, we find support for the environmental Kuznets curve for some pollutants and for its rejection in other cases. The fresh specification offers some promise for analysis of such phenomena.
\end{abstract}

David F. Bradford

Woodrow Wilson School

Princeton University

Princeton, NJ 08544-1013

609-258-1856

and NBER

bradford@princeton.edu

Stephen H. Shore

111 Kirkland Mail Center

95 Dunster Street

Cambridge, MA 02138

617-493-2496

shore@fax.harvard.edu
Rebecca Schlieckert

Associate

Black Rock Financial Management 345 Park Avenue

New York, NY 10154

212-754-5556

rschliec@blackrock.com 


\section{The Environmental Kuznets Curve: Exploring A Fresh Specification}

David F. Bradford, Rebecca Schlieckert, and Stephen H. Shore

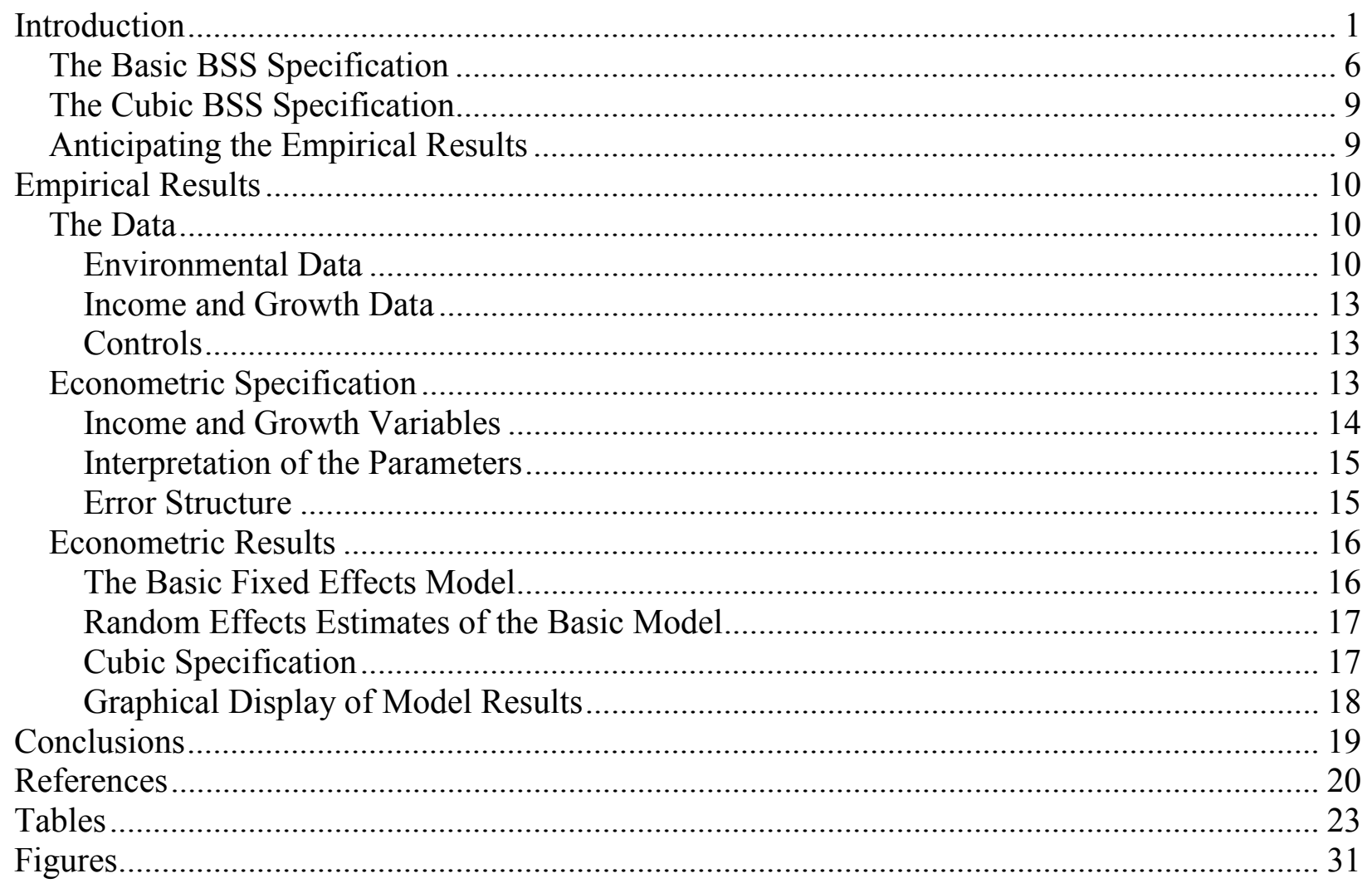




\title{
The Environmental Kuznets Curve: Exploring A Fresh Specification
}

\author{
David F. Bradford, Rebecca Schlieckert, and Stephen Shore*
}

\section{Introduction}

Since most phenomena understood as pollution tend to be related either to industrial production or consumption that come with high levels of material prosperity, one might expect a generally positive link between a country's income level and environmental pollution. This would be true even if environmental externalities were continually accounted for optimally in the usual economist's sense of balancing marginal benefit of regulation with marginal cost in nonenvironmental benefits foregone. At least two offsetting effects on the demand side of the system might be posited as people get richer. First, they may be prepared to pay more for environmental quality (environmental amenity is a normal good). Second, the composition of the consumption bundle might shift in the direction of less pollution-intensive goods, such as digitally recorded entertainment. There may also be offsetting effects on the supply side. The

\footnotetext{
* Bradford is Professor of Economics and Public Affairs, Princeton University; Adjunct Professor of Law, NYU Law School; Research Associate, National Bureau of Economic Research; CESifo Fellow. Schliekert is an associate at BlackRock Financial Management in New York City. Shore is a doctoral student in economics at Harvard University.
} 
high wages associated with high income might make pollution-intensive goods relatively expensive to produce. The technological change that generates higher incomes might be biased in favor of less pollution-intensive goods (like software services). General equilibrium effects in the world trading system might also give rise to systematic effects on the location of pollutionintensive production activities in countries at different stages of development.

A priori theory thus gives us no particularly clear prediction about the association between differences in income levels and pollution, either across countries or over time. The idea that, as an empirical matter, there is a tendency on balance for pollution to worsen as economies develop and then to improve as economies become rich, has come to be known as the environmental Kuznets curve (EKC) hypothesis. The term refers by analogy to the "inverted U" relationship between the level of economic development and the degree of income inequality pointed out by Simon Kuznets (1955) in his 1954 presidential address to the American Economic Association. Brought to prominence by the World Bank's 1992 World Development Report and papers prepared in connection with that report, a substantial literature has developed, debating the theoretical basis for such a regularity in environmental quality and the merits of the evidence relating thereto. ${ }^{1}$

This paper aims to add to the list an exploration that uses a new model specification and approach to estimation. The approach seems rather well adapted to the investigation of the environmental Kuznets curve, with regard to which the available evidence consists of a relatively

\footnotetext{
${ }^{1}$ See, in addition to Grossman and Krueger (1993, 1995), Andreoni and Levinson (1998), Antweiler, Copeland and Taylor, (1998), Arrow et al (1995), Beckerman (1992), Cropper and Griffiths (1994), Ekins (1997), Harbaught, Levinson and Wilson (2000), Hilton and Levinson (1998), Kahn (1998), Selden and Song (1994, 1995), Shafic and Bandyopadhyay (1992), Stern, Common and Barbier (1996), Torras and Boyce (1998).
} 
short panel of observations from economies at widely diverse levels of development and with idiosyncratic features that may be expected to have a significant influence on the environmental variables of interest.

These are the characteristics of the data used in an influential paper (1995) by Princeton's Gene Grossman and Alan Krueger (hereinafter GK). ${ }^{2}$ In their pioneering study they analyzed readings over a period of at most twelve years (water pollutants within the span 1979-1990 and air pollutants within the span 1977-1988) from instruments measuring levels of fourteen different water and air pollutants at multiple locations in sixty-six countries. Although they found considerable variation among different pollutants, GK concluded there was a detectable inverted U relationship between a country's income and the levels of most of the pollutants they examined. Relatively low and high levels of income tend to be associated with relatively low levels of pollution. Pollution tends to be highest at intermediate income levels.

GK made no claim to have tested a structural model of the determinants of pollution. Their finding is, however, most easily understood and described in structural, dynamic terms: A poor country does not have enough industrial activity to cause significant pollution. As the country develops economically, pollution grows. Furthermore, as its industrial potential improves, it becomes an attractive location for high-polluting industrial production. At some point, the opposing forces mentioned increase in importance. The pollution problem becomes bad enough to stir collective action to control it; at the same time, incomes rise enough for the country's residents to be prepared to pay for it. Simultaneously, there is a shift toward lowpolluting products, so that, beyond that point, pollution falls as income grows.

\footnotetext{
${ }^{2}$ Grossman and Krueger (1993) applied a similar method to data confined to air pollution.
} 
The GK finding attracted widespread interest and controversy. ${ }^{3}$ The immediate impetus for this paper is a somewhat serendipitous development of a novel specification of the Kuznets curve that we think has some attractive properties. Using the data and programs kindly provided by GK, we have applied the new specification to a reanalysis of the relationship between income and pollution. Our specification augments theirs in data description. The question is whether, or rather, for which pollutants, there is a signal in the data of some sort of inverted U. The spirit of our analysis, then, is to draw a weight-of-the-evidence conclusion from the data examined by GK. While we use the tools of hypothesis testing along the way, our approach is rather that of exploratory data analysis.

The data consist of observations of a variety of pollution indicators at several locations in each of several countries over several years. The countries differ in their levels of economic development, presenting the key variation of interest. The straight cross-sectional evidence poses, however, a long-standing econometric problem (recalling the cross section vs. time series studies of the consumption-income relationship). That is, the countries located at different levels of income might have inherently different, unobserved, characteristics. If presently rich countries happened to have the property of low pollution, a positive true relationship between income growth and pollution would be masked in the cross section. The same goes for presently poor or middle-income countries.

The basic ways to deal with this problem are to use fixed effects or random effects methods to analyze the relationship between pollution and income found in the panel data. The

\footnotetext{
${ }^{3}$ See the special issue of Environment and Development Economics, February 1996; see also Antweiler, Copeland and Taylor (1998), Torras and Boyce (1998), Stern, Common and Barbier (1996).
} 
fixed effects approach amounts to running a separate regression for each location on the relationship between income and pollution, with the requirement that the relationship be the same, up to the location-specific constant term, everywhere. (In principle, similar logic can be extended to the slopes or higher-order terms.) Because it effectively adds a parameter for each measurement station, fixed effects estimation imposes a severe cost in degrees of freedom. If the location-specific influence can be itself assumed to be appropriately random, degrees of freedom are saved and are exploited by random effects methods. ${ }^{4}$

In terms of the notation used in the present paper, the specification used by GK (1995) is given by

$$
P_{i t}=y_{i t} \beta_{1}+y_{i t}^{2} \beta_{2}+y_{i t}^{3} \beta_{4}+\bar{y}_{i t} \beta_{4}+\bar{y}_{i t-}^{2} \beta_{5}+\bar{y}_{i t}^{3} \beta_{6}+X_{i t}^{\prime} \beta_{7}+\varepsilon_{i t}
$$

where

$$
\begin{aligned}
i & =\text { measurement station } \\
P_{i t} & =\text { measure of pollution level at that station } \\
y_{i t} & =\text { per capita GDP in the country in which the station is located } \\
\bar{y}_{i t-} & =\text { average GDP per capita over the prior three years } \\
X_{i t} & =\text { a vector of covariates }
\end{aligned}
$$

Our reanalysis of the data brings to the estimation a fresh specification, whereby each country's income level $(y)$ and growth rate $(g)$ are reduced to single numbers (fixed crosssectionally). The trend rate of increase in pollution is assumed to depend on these two characteristics of an economy.

\footnotetext{
${ }^{4}$ In their work on air pollution Grossman and Krueger (1993) used both methods. The relevant coefficients indicating the EKC were significant by standard measures only for the random effects estimation.
} 


\section{The Basic BSS Specification}

What we refer to as the GK functional form expresses the level of pollutant in a country as a function of a cubic of the country's current and lagged per capita real GDP ("income"), plus time and various controls. (Particular interest attaches to the quadratic term in income, which gives rise potentially to the characteristic inverted $U$ shape.)

We arrived at the alternative functional form, which we call the BSS form, from the thought that the Kuznets curve phenomenon, if it exists, might relate more to the long-term growth trends in countries at different levels of development than to year-to-year variations in income. This led us to the following schematic model (2):

$$
\frac{d P}{d t}=\alpha\left(y-y^{*}\right) g
$$

where

- $\quad P$ refers to the level of pollutant registered at a particular location (mean concentration (in water) or median concentration (in air)), ${ }^{5}$

- $\quad y$ and $g$ are the level and rate of growth, respectively, of income in the country in question over the reference period,

- $t$ is time measured in years during the reference period and

- $\alpha$ and $y^{*}$ are constants (to be estimated in the empirical application) specific to the pollutant.

Note that the schematic omits an exogenous time trend and other controls that one might add.

\footnotetext{
${ }^{5}$ Henceforth, we use "mean" to refer to both these measures.
} 
For the cross-sectional estimation of the parameters of (2), we, in effect integrate it to obtain (3)

$$
P=\alpha\left(y-y^{*}\right) g t+\beta
$$

where $\beta$ is a constant of integration of (2).

Equation (2) describes a locally linear relationship between pollution and time at the location in question. The trend rate of increase in pollution depends upon the level of development (measured by $y$ ) of the country in which the measuring station is located and the rate of growth, $g$, of that country's economy. If $\alpha$ is less than zero, then for $y$ less than $y^{*}$, the more rapidly a country is growing, the more rapidly is pollution increasing. For $y$ greater than $y^{*}$, more rapidly a country is growing, the more rapidly is pollution decreasing. (If a country's rate of growth is negative, pollution will be trending down if the country is poor, trending up if the country is rich.) Thus, $y^{*}$ in this formulation indicates the location (in terms of development) of the top of the inverted U. A cross section snapshot of otherwise identical countries growing at the same positive rate (but having started at different times, so as to reach the various income levels at the time of the snapshot) would look like the graph shown in Figure 1. Alternatively, it could be thought of as the pollution path of a country with constant growth as it gets richer through time. 


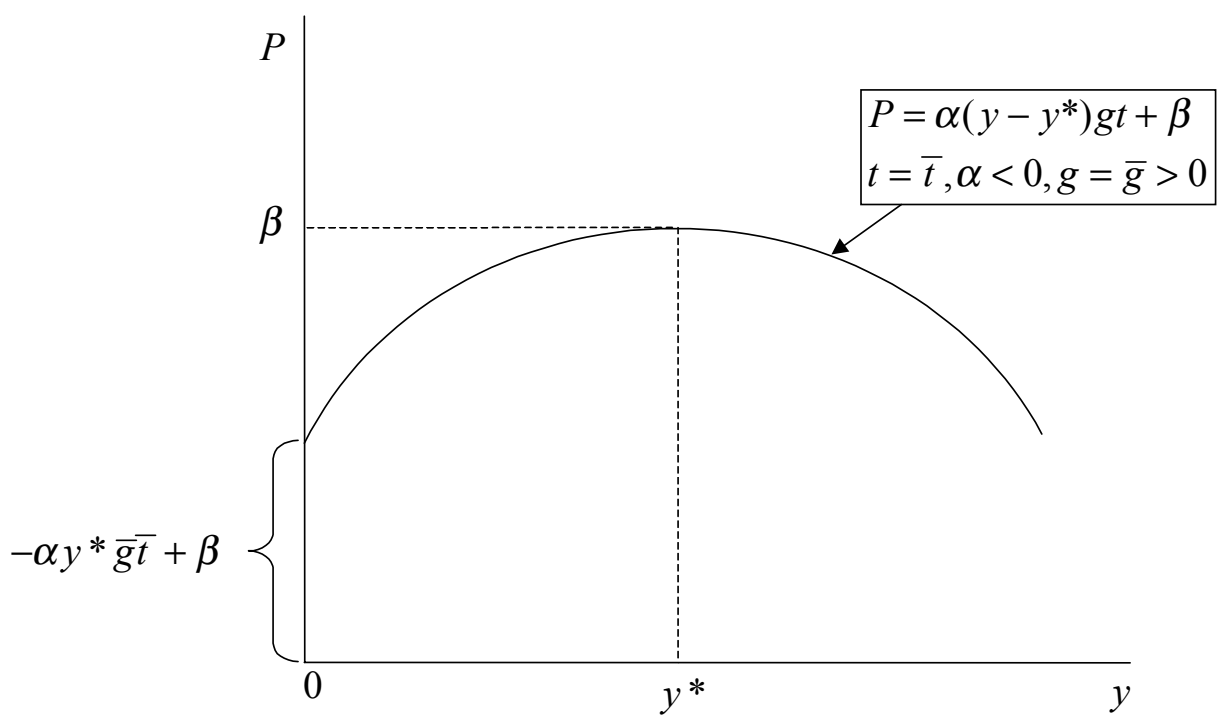

Figure 1. Cross Section at Time $\bar{t}$ of Economies Growing Constantly at the Same Rate, $\bar{g}$, with Different Starting Dates

Taking the GK specification as the more typical approach, we would note two features that distinguish the BSS approach:

- The income data are captured in two aggregates (average level and average growth rate); the GK specification uses actual year-by-year income (albeit while including lagged income variables that do some of the same smoothing as do our aggregates).

- The GK structure is a cubic in income (or more generally a polynomial); the BSS structure maps into a function of the logarithm of income and the product of income and its log.

To explain the latter point, suppose an economy were growing at a constant rate, $y=y_{0} e^{g t}$. We could then invert the growth function to express time as a function of income, $t=\left(\ln y-\ln y_{0}\right) / g$. Substituting in to the BSS form yields $P=\alpha\left(y-y^{*}\right)\left(\ln y-\ln y_{0}\right)+\beta$.

Differences in conclusions we may reach about the Kuznets curve from those of GK presumably trace to these differences in the approaches. 


\section{The Cubic BSS Specification}

Although our very parsimonious functional form does seem to give us the ability to detect the presence or absence of the inverted U phenomenon in the empirical record, we follow GK in looking as well at the somewhat more flexible cubic formulation (4) (expressed in its integrated form),

$$
P=\alpha\left(y-y^{*}\right)\left(y-y^{* *}\right) g t+\beta .
$$

GK concluded that for some pollutants concentration reached a peak at some level of income but then at higher levels the concentration appeared to trend up again. In specification (4), this pattern would be implied by a positive estimated value of $\alpha$, with $y^{*}$ indicating the top of the $\mathrm{U}$ and $y^{* *}$ indicating the income level at which pollution would tend up again.

\section{Anticipating the Empirical Results}

In spite of the heavy information requirements imposed by fixed effects estimation, perhaps because the BSS specification of the U-curve is so simple, we obtain coefficient estimates with sufficient statistical significance to draw conclusions about the Kuznets curve hypothesis by standard hypothesis testing standards. For the basic model, coefficients on $y g t$ and $y t$ as regressors together imply the position of the turning-point income value and whether the implied curve is inverted or not. In a very general sense, the inverted U-curve hypothesis can be tested by examining the properties of these coefficients. Assessing the coefficients derived from fixed effects estimation for statistical significance in the usual way, our results suggest that for some pollutants (arsenic, $\mathrm{COD}$, dissolved oxygen, lead, smoke, $\mathrm{SO}_{2}$ ), the effect is there; for others (coliform, nickel, nitrates) there exists and effect but not in the expected direction. (For still others, the hypothesis of no relationship cannot be rejected). 
As another way to assess the evidence in the regression relating to the environmental Kuznets curve we have explored the question whether the implied pollution-income relationship reaches a peak in the framework of income and growth levels within the span of historical experience. If the inverted $U$ hypothesis held, one would expect the time derivative of pollution predicted by our formulation to be positive for a country at a low level of income and negative for one at a high level of income, assuming both countries are growing at positive rate. On a bar graph with income categories on the horizontal axis, we would expect to see the bars march down from left to right, from positive to more and more negative (with the possibility of turning positive at high levels of income for the cubic version of the hypothesis). Using values of the income levels ( $\$ 1000, \$ 5000, \$ 10,000$ and $\$ 20,000)$ ranging from very low to a bit beyond the top level in the sample distribution, a growth rate of 3\% (fairly high but arbitrarily chosen for illustrative purposes) and point estimates of the coefficients, BOD is added to the list of winners. The details of these and other inferences are spelled out in the section on empirical results.

\section{Empirical Results}

The Data

\section{Environmental Data}

Since our main objective is to see what the data tell us using various approaches, we use exactly the same data employed by GK (1995). Their paper includes an excellent description of those data; we summarize the discussion here for purposes of a reasonably self-contained exposition.

Collected through the Global Environmental Monitoring System (GEMS), sponsored by a consortium of United Nations agencies, the environmental data set includes annual statistical 
summaries for the years $1977-88$ for the air pollutants and 1979-90 for the water contaminants. ${ }^{6}$ The aim of GEMS is "to improve the validity and comparability of environmental data globally and to provide for the collection and assessment of environmental data," and the wide use of the GEMS data in similar studies indicates that it is one of the most comprehensive sources of international environmental data available. Still, one should note some concerns about them:

- Because few stations have consistently reported data throughout the time period they do not comprise a balanced panel.

- Because countries do not send reports to the organization within a regulated time period, the most recent years have fewer observations. If countries that report conditions more promptly are those with stricter environmental laws and less pollution the environmental data in these years may be biased downward. On the other hand, if countries with more severe environmental problems inform GEMS sooner, we may witness an upward bias in overall environmental concentrations.

- There is also some concern that the selection of stations included in the sample is biased, for two different reasons. First, one might expect that since democratic countries value access to information more highly than non-democratic nations, stations located in democratic countries report data more frequently. Second, it seems possible that specific station sites are selected because of observed adverse environmental effects in the area. Therefore, when another station is added, one might anticipate that overall pollution as measured would

\footnotetext{
${ }^{6}$ The water pollution data are from "GEMS/WATER DATA SUMMARY 1988-90" $<$ http://www.cciw.ca/gems/summary/ intro.html> (26 March 1997). For the air pollutants, GK (1995, footnote 2) report "The GEMS data for 1977-1984 are published by the WHO in the series 'Air Quality in Selected Urban Areas.' We obtained unpublished data for 1985-1988 from the U.S. EPA."
} 
increase. GEMS has tried to avoid this selection bias by establishing stations at major sources of water supply for municipalities, irrigation, livestock, and selected industries. They also include baseline stations where it is believed that humans have not polluted the area at all.

The pollutants studied by GK and in this paper are arsenic, biological oxygen demand (BOD), cadmium, chemical oxygen demand (COD), total coliform ("coliform" in our tables and charts), fecal coliform, dissolved oxygen (a "good," rather than a "bad"), lead, mercury, nickel, and nitrate in water, and smoke, suspended particles and sulphur dioxide $\left(\mathrm{SO}_{2}\right)$ in air in urban areas. The number of countries with data in each category ranges from 10 (nickel) to 52 (dissolved oxygen). These countries are listed in Table 1. Typically, a country has several monitoring stations; by 1990 the GEMS program included 287 river stations. The yearly statistics are derived from readings taken as frequently as biweekly for water and daily for air. GK discarded observations from lake and groundwater stations and focused on river basins, the category for which the most data are available.

There is a slight difference in the measures used by GK for the water pollutants and the air pollutants. For the former, the environmental indicator used is the arithmetic mean of the year's readings, for the latter, the annual median. The mean value is the preferred measure because it evaluates more stations. Medians are only reported if a station has four or more values during the year. However, the median must be used for the air data because GEMS/AIR did not provide mean values.

Table 2 provides a summary of the environmental data. It includes the mean level of each pollutant and the standard deviation, both of which are calculated across all stations over 
the entire time period. For several pollutants, we note large standard deviations relative to the mean. From this relationship we infer that the distributions are not all necessarily bell-shaped. Income and Growth Data

The GDP per capita data used by GK are from Summers and Heston's (1991) Penn World Tables Mark 5.6. All values are expressed in 1985 U.S. dollars. All references made herein to income and GDP are in per capita terms.

\section{$\underline{\text { Controls }}$}

GK's estimation incorporated a variety of controls for factors, other than level of development, that would be expected to influence pollution levels. For air pollutants these include population density and dummy variables indicating proximity to a coast or desert, and location in a central city or residential or industrial area. The mean water temperature is included for water pollutants because warmer water will dissolve a greater quantity and variety of chemicals, releasing them into the aquatic environment. Because methods of measurement may vary, regressions for some types of pollutants also include dummy variables for the type of measuring device used.

$\underline{\text { Econometric Specification }}$

For estimation, we expand the specification of the relationship for each pollutant as

$$
P_{i, t}=\alpha\left(y_{i}-y_{i}^{*}\right) g_{i} t+\beta^{\prime} Z_{i, t}+\lambda t+\varepsilon_{i, t},
$$

where

- $\quad i$ indicates the measurement station,

- $Z_{i, t}$ is a vector of station control variables and

- $t$ is the year of the observation. 
As has been discussed, the pollution variables are annual means of the measured levels. (In the cases of fecal and total coliform the log of the annual means is used because the levels of these pollutants display exponential growth and highly skewed distributions. In order to allow for readings of zero, the variables used for the regressions are $\log (1+P)$.)

We discuss below alternative assumptions about the error term, $\varepsilon_{i, t}$.

\section{$\underline{\text { Income and Growth Variables }}$}

The variable $y_{i}$ is a level indicator of the GDP per capita of the country in which the station is located and $g_{i}$ is an indicator of the country's rate of economic growth. All stations within the same country are assigned the same values of $y_{i}$ and $g_{i}$. Consistent with GK, whose income variables are all in per capita terms, the basic version of our model takes as the measure of the rate of growth an average of the rate of increase in per capita GDP over a reference period. Specifically, the variable $g$ was calculated by first taking a four-year average (to minimize the effect of short-term cyclical influences) of GDP per capita at the start of the period of observations and a four-year average at the end of this period. The first average was of 1979-82 for all stations, ${ }^{7}$ and the second of $1989-92$ for most stations. In the small number of cases where the Summers and Heston data for a country do not extend to 1992, an earlier four-year period is used. The rate of growth for a country is that exponential rate that takes the average in the first period to the average in the second period; i.e., the difference between the natural logs of the two

\footnotetext{
${ }^{7}$ Because we study more water pollutants than air pollutants, we used 1979 as the first observation year instead of 1977, when air pollution observations began. Also, Summers and Heston provided no income data for Kuwait until 1980, so the period 1980-83 was substituted for Kuwait's first average.
} 
values divided by the time span (measured from the midpoints of the early income values and later income values, usually equal to 1990.5-1980.5).

The value of $y_{i}$ is obtained by taking the same four-year average of GDP per capita from the start of the period of observations (1979-82) and using the rate of growth just described to extrapolate to 1985.5 , the midpoint of the years for which income data were available for most countries. Using a level indicator for income de-emphasizes year-to-year fluctuations -- GK used lagged income in their model with a similar objective. Table 3 provides a list of the calculated income and growth values for the individual countries.

\section{Interpretation of the Parameters}

The parameter $y^{*}$ is the income level at which the concentration levels begin to fall under the Kuznets curve inverted U hypothesis (or rise in the case of a U-shape). Because the coefficients to be estimated on $y g t$ and $g t$ are $\alpha$ and $\alpha y^{*}$, respectively, the estimate of $y^{*}$ is

found implicitly by calculating the ratio of the coefficients, $\frac{\alpha y^{*}}{\alpha}$. The other coefficient of critical interest is $\alpha$ itself. A negative value indicates the inverted $U$ shape of the Kuznets curve.

The coefficient of $t$ is intended to capture a possible exogenous worldwide trend in the level of the pollutant in question.

\section{$\underline{\text { Error Structure }}$}

To address the problem of locationally idiosyncratic but unobservable variation in conditions, we use a fixed effects estimator of the coefficients in (5) and for the econometric analogue of (4).

GK used random effects estimation in their analysis. The general model is 


$$
P_{i, t}=\gamma+\delta^{\prime} x_{i, t}+u_{i}+\varepsilon_{i, t},
$$

where $P$ is pollution, $x_{i t}$ is a vector of all regressors over stations over time, $u_{i}$ is a station-specific

error, and $\varepsilon_{i, t}$ is a random disturbance over time and across stations. The applicability of random effects methods depends, however, upon the regressors being uncorrelated with the countryspecific error term, $u_{i}$. We note that this condition is not especially plausible a priori. We would not expect the controls such as proximity to a desert to be uncorrelated with the station. For our specification a Hausman test rejects the random effects assumptions for most cases. Some would, however, question relying on the Hausman test ${ }^{8}$ and so we also report the random effects results.

\section{$\underline{\text { Econometric Results }}$}

\section{The Basic Fixed Effects Model}

Table 4 displays the coefficients on $y g t, g t, t$ and the implied $y^{*}$ values from the fixed effects estimation. The usual conventions have been followed to indicate the level of statistical significance. Because many of the variables used as regressors are time invariant -- such as those relating to location -- these fall out of the fixed effects estimation. Only the mean temperature of the water and the type of measuring instrument vary over time and remain in the estimation.

By examining the signs of $\alpha$ we can determine whether the implied shape is a $\mathrm{U}$ or an inverted-U. A positive $\alpha$ indicates a $\mathrm{U}$-shape, and a negative $\alpha$, an inverted-U. As indicated in Table 4, the estimates for arsenic, COD, dissolved oxygen (as a direct measure of environmental quality), lead, smoke, and sulphur dioxide indicate the inverted-U shape at a ninety percent 
confidence level or better. For total coliform, nickel and nitrates the estimates indicate a Ushaped relationship between income and pollution, the opposite of the environmental Kuznets curve hypothesis. (By contrast, GK find support for an inverted-U shape for all pollutants, except for suspended particles, which decrease monotonically.)

The shape of the pollution-income relationship in the relevant range is not completely determined by the sign of the coefficient, $\alpha$, however. The location of $y^{*}$ is also important. For $\mathrm{COD}$, the point estimate of the turning point is negative and for dissolved oxygen it is at a low level of income. For these pollutants the estimated path falls continuously, which might, however, be taken as in keeping with the spirit of the Kuznets hypothesis.

\section{$\underline{\text { Random Effects Estimates of the Basic Model }}$}

Table 5 presents the results of the random effects estimation for the basic BSS specification. Compared with the fixed effects estimates, COD and smoke drop from the list for which there is support for the Kuznets curve; nickel is added; coliform joins the list with the wrong shape. The last column of the table also shows the results of the Hausman specification test of the null hypothesis that the regressors in a random effects estimation are uncorrelated with the station-specific residuals. In only two cases is the probability more than $10 \%$ that the assumptions needed for random effects estimation hold.

\section{Cubic Specification}

Table 6 presents the result of estimating the cubic version of the BSS model. The environmental Kuznets Curve would imply a positive value for alpha. BOD, COD, lead, and sulphur dioxide stay on the list with significant support in this regard. For COD and lead,

\footnotetext{
${ }^{8}$ See Antweiler, Copeland and Taylor (1998).
} 
however, the estimated turning points are negative or very low. Although the sign of the alpha for dissolved oxygen is "wrong," (since it is a good, the sign of alpha should be negative) and in that sense does not support the environmental Kuznets curve, the estimates imply a peak level at $y^{* *}$ at a level comparable to that of sulphur dioxide. We therefore regard the cubic estimate as favoring the Kuznets curve for dissolved oxygen.

Table 7 presents random effects estimates of the coefficients of the cubic BSS model, along with the Hausman test statistics.

\section{Graphical Display of Model Results}

The graphs presented in Figure 2 through Figure 15 show the implications of three estimated relationships for the rate of change of the level of pollution for countries ranging from very low to very high income levels, each growing at the same rate. The idea is to visualize the validity of the environmental Kuznets curve hypothesis over (and slightly beyond) the range of historical experience. If the income level of the low-income country is below the peak of the inverted $\mathrm{U}$, and the income level of the high-income country is above the peak, then the bars on the left of the graphs should be positive and those on the right, negative, marching down from left to right.

To facilitate comparison across the pollutants in the strength of any effect, we carry over to the graphs the measurement of pollution in units of standard deviation in the entire sample of observations. This choice of units allows the reader to get a sense for whether effects are "large" with respect to the different pollutants. In each case, we show the value of $d P / d t$ implied by the standard BSS model, the cubic BSS model, and the GK model. The two BSS models are 
estimated using fixed effects; the GK model is estimated using random effects, employing the program provided to us by GK. The error bars show the $95 \%$ confidence intervals.

The confidence intervals on the time derivatives serve their usual function of indicating the strength of the evidence in the data for the signs and we include them in the pictures for that reason. At the same time, it should be recognized that they do not directly inform us about the evidence relating to the environmental Kuznets curve. For that purpose we would need a test of the hypothesis that the derivatives go from positive to negative as the income levels increase. ${ }^{9}$

Looking just at the point estimates of the time derivatives to draw conclusions about the environmental Kuznets curve, the GK results support the environmental Kuznets curve hypothesis for all pollutants, although for seven out of the fourteen pollutants the evidence implies the curve turns up again at high incomes, suspended particles decline with income throughout the range (arguably consistently with the EKC view) and for coliform the inverted U appears only very early and very weakly. GK support for nitrates and cadmium are fairly muted, as the initial derivative is negative. The BSS specifications reject an $\mathrm{EKC}$ for coliform fecal coliform, nickel, nitrates and suspended particles; they agree in supporting an EKC finding BOD, COD (which, however, declines with income throughout), dissolved oxygen, and sulphur dioxide. For the rest, the picture is mixed.

\section{Conclusions}

Table 8 summarizes the interpretations we draw from the fresh analysis. As a crude device to pull together the signal in the evidence as explored here, to each pollutant we assign a score of 1 for an entry of Y (supports a straight EKC) or YN (supports an EKC with an upturn at 
high incomes; a score of .5 for an entry of "?" (the relevant coefficient is statistically insignificant). On the basis of this ad hoc device, and in the spirit of exploratory analysis, arsenic, BOD, COD, dissolved oxygen, lead and sulphur dioxide would seem to invite for further investigation as to the validity of the EKC hypothesis. Coming in close are cadmium, mercury, and smoke. Pretty definitely not: (total) coliform, fecal coliform, nickel, nitrates, and suspended particles. Whether or not readers agree with this jury's verdict, we hope to have persuaded them of the utility of our addition to the bag of specification/estimation tricks for thinking about the Kuznets curve phenomenon.

\section{$\underline{\text { References }}$}

Andreoni, James, and Arik Levinson, "The Simple Analytics of the Environmental Kuznets Curve,” NBER Working Paper No. 6739, Cambridge, MA: National Bureau of Economic Research, September 1998.

Antweiler, Werner, Brian R. Copeland, and M. Scott Taylor, "Is Free Trade Good for the Environment?" NBER Working Paper No. 6707, Cambridge, MA: National Bureau of Economic Research, August 1998.

Arrow, Kenneth J., B. Bolin, R. Costanza, P. Dasgupta, C. Folke, C.S. Holling, B.O. Jansson, S. Levin, K.G. Maler, C. Perrings, D. Pimentel, "Economic Growth, Carrying Capacity, and the Environment," Science 268: 520-521, April 28, 1995.

Beckerman, Wilfred, "Economic Growth and the Environment: Whose Growth? Whose Environment?" World Development (XX) 1992, pp. 481-496.

\footnotetext{
${ }^{9}$ The cubic specifications would allow for the curve to turn up again for high incomes.
} 
Cropper, M. and C. Griffiths, "The Interaction Of Populations, Growth and Environmental Quality," American Economic Review (LXXXIV) 1994, pp. 250254.

Ekins, P., "The Kuznets Curve for the Environment and Economic Growth: Examining the Evidence" Environment and Planning (XXIX-5) 1997, pp. 805-830.

Grossman, Gene M., and Alan Krueger, "Environmental Impacts of a North American Free Trade Agreement," in Peter Garber, ed., The Mexico-U.S. Free Trade Agreement, Cambridge, MA: MIT Press, 1993, pp. 13-56.

Grossman, Gene M., and Alan Krueger, "Economic Growth and the Environment," Quarterly Journal of Economics, (CX-2) May 1995, pp. 353-377.

Harbaugh, William, Arik Levinson, and David Wilson, "Reexamining the Empirical Evidence for an Environmental Kuznets Curve," NBER Working Paper No. 7711, Cambridge, MA: National Bureau of Economic Research, May 2000.

Hilton, F.G. Hank and Arik Levinson, "Factoring the Environmental Kuznets Curve: Evidence from Automotive Lead Emissions," Journal of Environmental Economics and Management (XXXV) 1998, pp. 126- 141.

Kahn, Matthew E., "A Household Level Environmental Kuznets Curve" Economics Letters (LIX-2) 1998, pp. 269-273.

Kuznets, Simon, "Economic Growth and Income Inequality" American Economic Review (XLV-1) 1955, pp. 1-28. 
Selden, Thomas M. and Daqing Song, "Environmental quality and development: Is there a Kuznets Curve for air pollution emissions?" Journal of Environmental Economics and Management, (XXVII) 1994, pp. 147-162.

Selden, Thomas M. and Daqing Song, "Neoclassical Growth, the J Curve for Abatement, and the Inverted U Curve for Pollution," Journal of Environmental Economics and Management, (XXIX-2) 1995, pp. 162-68.

Shafik, N. and S. Bandyopadhyay, "Economic Growth and Environmental Quality: Time Series and Cross-Section Evidence," World Bank Policy Research Working Paper \#WPS904. Washington, D.C.: The World Bank, 1992.

Stern, David I., Michael S. Common and Edward B. Barbier, "Economic Growth and Environmental Degradation: The Environmental Kuznets Curve and Sustainable Development" World Development (XXIV-7), 1996, pp. 1151-1160.

Summers, Robert, and Alan Heston, "The Penn World Table (Mark 5): An Expanded Set of International Comparisons, 1950-1988," Quarterly Journal of Economics, (CVI-2) May 1991, 327-69.

Torras, Mariano and James K. Boyce. "Income, Inequality, and Pollution: A Reassessment of the Environmental Kuznets Curve," Ecological Economics (XXV-2) May 147-160.

World Bank, Development and the Environment, World Development Report 1992, NY: Oxford University Press, 1992. 


\section{Tables}

\begin{tabular}{|c|c|c|c|c|c|c|c|c|c|c|c|c|}
\hline & & & & & & Countries Repo & orting Pollutant Levels & & & & & \\
\hline Arsenic & BOD & Cadmium & COD & Coliform (total) & Dissolved Oxygen & Fecal Coliform & Lead & Mercury & Nickel & Nitrate & Smoke & Suspended Particles \\
\hline AUSTR ALIA & ARGENTINA & AUSTRALIA & BELGIUM & ARGENTINA & ARGENTINA & ARGENTINA & AUSTRAULA & ARGENTINA & AUSTRAULA & ARGENTINA & ARGENTINA & ARGENTINA \\
\hline $\begin{array}{l}\text { AUSLGIUM } \\
\text { BELIU }\end{array}$ & BANGLADESH & $\begin{array}{l}\text { AUSTRALIA } \\
\text { BELIUM }\end{array}$ & $\begin{array}{l}\text { BELGIMM } \\
\text { BRAZIL }\end{array}$ & BELGIUM & AUSTRALIA & AUSTRALIA & $\begin{array}{l}\text { AUSTALLA } \\
\text { BELIUM }\end{array}$ & AUSTRALIA & $\begin{array}{l}\text { AUDLALLA } \\
\text { BELIUM }\end{array}$ & $\begin{array}{l}\text { ARGENINA } \\
\text { AUSTRALIA }\end{array}$ & $\begin{array}{l}\text { ARGELIINA } \\
\text { BELGIUM }\end{array}$ & $\begin{array}{l}\text { ARGENIIIA } \\
\text { AUSTRALIA }\end{array}$ \\
\hline BRAZIL & BELGIUM & BRAZIL & CHILE & BRAZIL & BANGLADESH & BANGLADESH & BRAZIL & BELGIUM & BRAZIL & BANGLADESH & BRAZIL & BELGIUM \\
\hline CANADA & BRAZIL & CANADA & COLOMBIA & CHILE & BELGIUM & BELGIUM & CANADA & BRAZIL & CANADA & CANADA & CHILE & BRAZIL \\
\hline CHILE & CANADA & COLOMBIA & DENMARK & CHINA & BRAZIL & BRAZIL & FINLAND & CANADA & JAPAN & CHILE & COLOMBIA & CANADA \\
\hline CHINA & CHILE & DENMARK & FINLAND & COLOMBIA & CANADA & CANADA & HUNGARY & CHINA & MALAYSIA & CHINA & DENMARK & CHINA \\
\hline FINLAND & CHINA & FINLAND & FRANCE & FIJI & CHILE & CHILE & INDONESIA & DENMARK & NETHERLANDS & COLOMBIA & $\begin{array}{l}\text { EGYPT } \\
\end{array}$ & COLOMBIA \\
\hline INDONESIA & COLOMBIA & HUNGARY & HUNGARY & FINLAND & CHINA & CHINA & JAPAN & FINLAND & PHILIPPINES & ECUADOR & FRANCE & DENMARK \\
\hline JAPAN & DENMARK & INDONESIA & INDIA & HUNGARY & COLOMBIA & COLOMBIA & KENYA & FRANCE & UNITED KINGDO & MEGYPT & GREECE & FINLAND \\
\hline MALAYSIA & ECUADOR & IRELAND & INDONESIA & INDIA & DENMARK & DENMARK & MALAYSIA & HUNGARY & UNITED STATES & FIJI & HONG KONG & GHANA \\
\hline NETHERLANDS & EGYPT & ITALY & $\begin{array}{l}\text { INDELESDA } \\
\text { IREAND }\end{array}$ & JAPAN & $\begin{array}{l}\text { ECUADOR } \\
\text { ECUAR }\end{array}$ & $\begin{array}{l}\text { DENMARK } \\
\text { ECUADOR }\end{array}$ & $\begin{array}{l}\text { MAAAYSSIA } \\
\text { MEXICO }\end{array}$ & $\begin{array}{l}\text { UUNGARRY } \\
\text { INDONESIA }\end{array}$ & UNITED STATES & $\begin{array}{l}\text { FIJI } \\
\text { FINLAND }\end{array}$ & $\begin{array}{l}\text { HONG KONG } \\
\text { IRAN }\end{array}$ & $\begin{array}{l}\text { GHANA } \\
\text { GREECE }\end{array}$ \\
\hline NEW ZEALAND & FIJI & JAPAN & ITALY & KENYA & EGYPT & FIJI & NETHERLANDS & $\begin{array}{l}\text { IRELAND } \\
\text { IRE }\end{array}$ & & GUATEMALA & IRELAND & HONG KONG \\
\hline PORTUGAL & FRANCE & KENYA & JAPAN & MALAYSIA & FIJI & FRANCE & NORWAY & ITALY & & HUNGARY & NEW ZEALAND & INDIA \\
\hline THAILAND & GUATEMALA & LUXEMBOURG & KENYA & MEXICO & FINLAND & GUATEMALA & PORTUGAL & JAPAN & & INDIA & PERU & INDONESIA \\
\hline TURKEY & HUNGARY & MALAYSIA & LUXEMBOURG & NEW ZEALAND & FRANCE & HUNGARY & REP. OF KOREA & LUXEMBOURG & & INDONESIA & POLAND & IRAN \\
\hline UNITED KINGDO & GINDIA & MEXICO & MALAYSIA & PAKISTAN & GUATEMALA & INDIA & THAILAND & MALAYSIA & & IRAN & PORTUGAL & IRAO \\
\hline UNITED STATES & INDONESIA & NETHERLANDS & MEXICO & PHILIPPINES & HUNGARY & INDONESIA & $\begin{array}{l}\text { TURKEY } \\
\text { TUE }\end{array}$ & MEXICO & & IRELAND & SPAN & ISAQ \\
\hline & IRAN & NORWAY & NETHERLANDS & PORTUGAL & INDIA & IRAN & UNITED KINGDOM & U NETHERLANDS & & JAPAN & UNITED KINGDOM & $\begin{array}{l}\text { ISRAEL } \\
\text { IJAPAN }\end{array}$ \\
\hline & IRELAND & PAKISTAN & NEW ZEALAND & TANZANIA & INDONESIA & IRELAND & UNITED STATES & NEW ZEALAND & & KENYA & VENEZUELA & KENYA \\
\hline & $\begin{array}{l}\text { ITALY } \\
\text { ITALY }\end{array}$ & $\begin{array}{l}\text { PALISIPIN } \\
\text { PHIPINES }\end{array}$ & $\begin{array}{l}\text { PAKISTAN } \\
\text { PAKT }\end{array}$ & $\begin{array}{l}\text { THILANA } \\
\text { THAILAND }\end{array}$ & & ITALY & URUGUAY & $\begin{array}{l}\text { NEW LEALAND } \\
\text { PHLIPPINES }\end{array}$ & & MALAYSIA & & $\begin{array}{l}\text { RENAA } \\
\text { KUWAIT }\end{array}$ \\
\hline & JAPAN & PORTUGAL & $\begin{array}{l}\text { PAAIIIAN } \\
\text { PHILIPINES }\end{array}$ & $\begin{array}{l}\text { HAIAND } \\
\text { TURKEY }\end{array}$ & $\begin{array}{l}\text { IRAN } \\
\text { IRELAND }\end{array}$ & JAPAN & & $\begin{array}{l}\text { PORTUGAL } \\
\text { POLAL }\end{array}$ & & $\begin{array}{l}\text { MALAYYIA } \\
\text { MEXICO }\end{array}$ & & $\begin{array}{l}\text { MUWAII } \\
\text { MALAYSIA }\end{array}$ \\
\hline & KENYA & REP. OF KOREA & PORTUGAL & URUGUAY & ITALY & LUXEMBOURG & & REP. OF KOREA & & NETHERLANDS & & NEW ZEALAND \\
\hline & LUXEMBOURG & THAILAND & REP. OF KOREA & & JAPAN & MALAYSIA & & THAILAND & & NEW ZEALAND & & PAKISTAN \\
\hline & $\begin{array}{l}\text { MALAYSIA } \\
\text {. }\end{array}$ & UNITED KINGDON & M SRILANKA & & KENYA & MEXICO & & TURKEY & & NORWAY & & PHILIPINES \\
\hline & $\begin{array}{l}\text { MALAYSIA } \\
\text { MALI }\end{array}$ & UNITED STATES & $\begin{array}{l}\text { MSSILANKA } \\
\text { THAILAND }\end{array}$ & & $\begin{array}{l}\text { KENYA } \\
\text { LUXEMBOURG }\end{array}$ & NETHERLANDS & & $\begin{array}{l}\text { UNITED KINGDOM } \\
\text { UNGE }\end{array}$ & & $\begin{array}{l}\text { NAKISTAN } \\
\text { PAKIT }\end{array}$ & & PORTUGAL \\
\hline & MAROC & URUGUAY & TURKEY & & MALAYSIA & NEW ZEALAND & & UNITED STATES & & PANAMA & & THAILAND \\
\hline & MEXICO & W. GERMANY & UGANDA & & MALI & NORWAY & & URUGUAY & & PERU & & UNITED STATES \\
\hline & NETHERLANDS & & UNITED KINGDOM & & MAROC & PAKISTAN & & W. GERMANY & & PORTUGAL & & VENEZUELA \\
\hline & NEW ZEALAND & & UNITED STATES & & MEXICO & PANAMA & & & & SENEGAL & & W. GERMANY \\
\hline & PAKISTAN & & W. GERMANY & & NETHERLANDS & PERU & & & & SPAIN & & YUGOSLAVIA \\
\hline & PANAMA & & ZAIRE & & NEW ZEALAND & PHILIPPINES & & & & SUDAN & & \\
\hline & PHILIPPINES & & & & NORWAY & PORTUGAL & & & & SWEDEN & & \\
\hline & PORTUGAL & & & & PAKISTAN & REP. OF KOREA & & & & TANZANIA & & \\
\hline & REP. OF KOREA & & & & PANAMA & SPAIN & & & & THAILAND & & \\
\hline & SPAIN & & & & PERU & SRILANKA & & & & TUNISIE & & \\
\hline & SRILANKA & & & & PHILIPPINES & TANZANIA & & & & TURKEY & & \\
\hline & SUDAN & & & & PORTUGAL & THAILAND & & & & UNITED KINGDOM & & \\
\hline & TANZANIA & & & & REP. OF KOREA & TUNISIE & & & & UNITED STATES & & \\
\hline & THAILAND & & & & SENEGAL & TURKEY & & & & URUGUAY & & \\
\hline & TUNISIE & & & & SPAIN & UNITED KINGDOM & & & & W. GERMANY & & \\
\hline & TURKEY & & & & SRILANKA & UNITED STATES & & & & & & \\
\hline & UNITED KINGDOM & & & & SUDAN & URUGUAY & & & & & & \\
\hline & UNITED STATES & & & & TANZANIA & & & & & & & \\
\hline & URUGUAY & & & & THAILAND & & & & & & & \\
\hline & W. GERMANY & & & & TUNISIE & & & & & & & \\
\hline & ZAIRE & & & & TURKEY & & & & & & & \\
\hline & & & & & UNITED KINGDOI & & & & & & & \\
\hline & & & & & UNITED STATES & & & & & & & \\
\hline & & & & & URUGUAY & & & & & & & \\
\hline & & & & & W. GERMANY & & & & & & & \\
\hline & & & & & ZAIRE & & & & & & & \\
\hline
\end{tabular}


Descriptive Statistics

Pollutant

Mercury

Arsenic

Cadmium

Dissolved Oxygen

Lead

Nickel

Nitrate

BOD

COD

Coliform (total)

Fecal coliform

Smoke*

Suspended particles*

Sulphur dioxide*

$\begin{array}{rrc}\text { Mean } & \begin{array}{r}\text { Standard } \\ \text { deviation }\end{array} & \text { Units } \\ 0.285 & 0.785 & \mu \mathrm{g} / \mathrm{L} \\ 0.00594 & 0.00947 & \mathrm{mg} / \mathrm{L} \\ 0.0435 & 0.165 & \mathrm{mg} / \mathrm{L} \\ 8.12 & 3.25 & \mathrm{mg} / \mathrm{L} \\ 0.0314 & 0.293 & \mathrm{mg} / \mathrm{L} \\ 0.00883 & 0.0111 & \mathrm{mg} / \mathrm{L} \\ 1.53 & 3.88 & \mathrm{mg} \mathrm{Nitrogen} / \mathrm{L} \\ 6.63 & 22.6 & \mathrm{mg} \mathrm{Oxygen} / \mathrm{L} \\ 48.4 & 119.434 & \mathrm{mg} \mathrm{Oxygen} / \mathrm{L} \\ 178000 & 943000 & \mathrm{No.} / 100 \mathrm{~mL} \\ 103000 & 599000 & \text { No./100mL } \\ 53.3 & 53.2 & \text { ug/cubic m } \\ 151 & 129 & \text { ug/cubic m } \\ 34.3 & 38.9 & \text { ug/cubic m }\end{array}$

*based on annual median concentration

Source: GEMS/WATER and GEMS/AIR databases

Table 2. Summary of Environmental Data 
Country Income and Growth

(sorted by income)

$\begin{array}{lrrlrr} & \text { Income } & \text { Growth } & & \text { Income } & \text { Growth } \\ \text { ZAIRE } & 460 & -0.01 & \text { REPUBLIC OF KOREA } & 4,742 & 0.08 \\ \text { TANZANIA } & 515 & 0.01 & \text { URUGUAY } & 4,869 & 0 \\ \text { MALI } & 527 & 0 & \text { HUNGARY } & 5,106 & 0 \\ \text { UGANDA } & 641 & -0.03 & \text { YUGOSLAVIA } & 5,142 & -0.02 \\ \text { SUDAN } & 808 & -0.01 & \text { ARGENTINA } & 5,498 & -0.02 \\ \text { KENYA } & 902 & 0 & \text { PORTUGAL } & 5,848 & 0.03 \\ \text { GHANA } & 906 & 0 & \text { MEXICO } & 5,968 & 0 \\ \text { INDIA } & 1,059 & 0.03 & \text { GREECE } & 6,333 & 0.01 \\ \text { CHINA } & 1,145 & 0.04 & \text { VENEZUELA } & 6,886 & -0.01 \\ \text { SENEGAL } & 1,152 & 0 & \text { U.S.S.R. } & 7,077 & 0.03 \\ \text { PAKISTAN } & 1,242 & 0.02 & \text { IRELAND } & 7,977 & 0.03 \\ \text { BANGLADESH } & 1,263 & 0.03 & \text { SPAIN } & 8,382 & 0.03 \\ \text { INDONESIA } & 1,644 & 0.04 & \text { ISRAEL } & 8,635 & 0.02 \\ \text { EGYPT } & 1,774 & 0.01 & \text { E. GERMANY } & 9,505 & 0.04 \\ \text { PHILIPPINES } & 1,798 & -0.01 & \text { NEW ZEALAND } & 11,006 & 0.01 \\ \text { BOLIVIA } & 1,825 & -0.02 & \text { ITALY } & 11,284 & 0.02 \\ \text { SRI LANKA } & 1,877 & 0.03 & \text { UNITED KINGDOM } & 11,521 & 0.02 \\ \text { GUATEMALA } & 2,331 & -0.01 & \text { HONG KONG } & 11,650 & 0.05 \\ \text { PERU } & 2,523 & -0.03 & \text { FINLAND } & 11,963 & 0.02 \\ \text { TUNISIE } & 2,718 & 0.01 & \text { BELGIUM } & 12,010 & 0.02 \\ \text { THAILAND } & 2,818 & 0.05 & \text { NETHERLANDS } & 12,040 & 0.02 \\ \text { ECUADOR } & 2,990 & -0.01 & \text { JAPAN } & 12,176 & 0.04 \\ \text { COLOMBIA } & 3,119 & 0.01 & \text { DENMARK } & 12,584 & 0.02 \\ \text { PANAMA } & 3,201 & -0.01 & \text { FRANCE } & 12,768 & 0.02 \\ \text { TURKEY } & 3,250 & 0.02 & \text { W. GERMANY } & 13,050 & 0.02 \\ \text { JORDAN } & 3,377 & -0.01 & \text { KUWAIT } & 13,065 & -0.05 \\ \text { IRAN } & 3,618 & -0.01 & \text { SWEDEN } & 13,380 & 0.02 \\ \text { FIJI } & 3,634 & 0 & \text { AUSTRALIA } & 13,406 & 0.02 \\ \text { IRAQ } & 4,042 & -0.09 & \text { NORWAY } & 13,461 & 0.02 \\ \text { BRAZIL } & 4,068 & 0 & \text { LUXEMBOURG } & 13,968 & 0.03 \\ \text { POLAND } & 4,095 & -0.01 & \text { SWITZERLAND } & 15,126 & 0.01 \\ \text { CHILE } & 4,138 & 0.02 & \text { CANADA } & 15,436 & 0.02 \\ \text { MALAYSIA } & 4,520 & 0.03 & \text { U.S.A. } & 16,577 & 0.02 \\ & & & & & \end{array}$

Source: Authors' calculation; see text for details

Table 3. Country Income and Growth Data 


\section{Basic BSS Model \\ Fixed Effects Estimates}

Model Specification Implemented as

$\quad$ Pollutant
arsenic
BOD
cadmium
COD
coliform
dissolved O2
fecal coliform
lead
mercury
nickel
nitrates
smoke
so2
suspended particles

$\mathrm{P}=$ alpha $(\mathrm{y}-\mathrm{y} *) \mathrm{gt}+$ beta*t+(temperature controls $)+\mathrm{C}$

$\mathrm{P}=\mathrm{a} 1 *(\mathrm{ygt})+\mathrm{a} 2 *(\mathrm{gt})+\mathrm{a} 3 * \mathrm{t}+($ temperature controls $)+\mathrm{C}$

(Pollutants are scaled in percent of the standard deviation of the observations in the sample.)

\begin{tabular}{lrlrlrrr} 
ygt coeff & ygt z-stat & \multicolumn{1}{c}{ gt coeff } & gt z-stat & \multicolumn{1}{c}{ t coeff } & t z-stat & \multicolumn{1}{c}{ alpha } & \multicolumn{1}{c}{$y^{*}$} \\
$-0.02740754(* * *)$ & -2.812 & $363.07195(* * *)$ & 2.633 & -1.08187641 & -0.377 & -0.02740754 & 13247 \\
-0.00664293 & -1.601 & 7.55860 & 0.213 & 0.42558436 & 0.525 & -0.00664293 & 1138 \\
-0.00026747 & -0.018 & -4.14508 & -0.023 & 3.66637735 & 1.142 & -0.00026747 & -15497 \\
$-0.01215113(*)$ & -1.805 & $-114.55787(* *)$ & -2.359 & $4.42480853(* * *)$ & 3.444 & -0.01215113 & -9428 \\
$0.03738792(* * *)$ & 4.459 & $-336.48291(* * *)$ & -4.139 & $11.68690520(* * *)$ & 4.544 & 0.03738792 & 9000 \\
$0.01009395(* * *)$ & 4.134 & -12.04056 & -0.684 & $-1.20243041(* *)$ & -2.26 & 0.01009395 & 1193 \\
0.00000003 & 0.994 & 0.00003 & 0.134 & $0.00001382(* * *)$ & 2.586 & 0.00000003 & -1263 \\
$-0.01059726(* * *)$ & -3.861 & $109.05392(* * *)$ & 3.392 & 0.29839077 & 0.487 & -0.01059726 & 10291 \\
0.01174342 & 0.675 & 83.18447 & 0.422 & $-8.02615632(* *)$ & -2.483 & 0.01174342 & -7083 \\
$0.15985613(* *)$ & 2.343 & $-2019.78855(* *)$ & -2.532 & -4.89468569 & -1.184 & 0.15985613 & 12635 \\
$0.01297263(* *)$ & 2.053 & $-137.14704(* * *)$ & -2.682 & -0.04296918 & -0.035 & 0.01297263 & 10572 \\
$-0.03471547(* * *)$ & -3.613 & $415.63746(* * *)$ & 4.253 & $-3.89550901(* * *)$ & -4.491 & -0.03471547 & 11973 \\
$-0.03096669(* * *)$ & -7.927 & $94.60559(* *)$ & 2.397 & 0.05695148 & 0.065 & -0.03096669 & 3055 \\
-0.00364225 & -1.157 & $103.02904(* * *)$ & 4.309 & $-2.30705971(* * *)$ & -2.939 & -0.00364225 & 28287
\end{tabular}

Table 4. BSS Model: Fixed Effects Estimates 
Model Specification ? Implemented as

(Pollutants are scaled in percent of the standard deviation of the observations in the sample.)

\section{Basic BSS Model}

\section{Random Effects Estimates}

$\quad$ Pollutant
arsenic
BOD
cadmium
COD
coliform
dissolved O2
fecal coliform
lead
mercury
nickel
nitrates
smoke
so2
suspended particles

ygt coeff
$-0.00016445\left(^{* \star *}\right)$
0.00002063
-0.00001364
0.00002744
$0.00008390\left(^{*}\right)$
$0.00013296\left(^{* * *}\right)$
$1.74050831 \mathrm{E}-10$
$-0.00003320\left(^{* \star *}\right)$
$\left.-0.00001173{ }^{*}\right)$
$-0.00015531\left(^{* *}\right)$
$0.00007869\left(^{* *}\right)$
-0.00012069
$-0.00004554\left(^{* *}\right)$
-0.00020979

$\begin{array}{rc}\text { ygt z-stat } & \text { gt coeff } \\ -3.359 & 0.78472102 \\ 0.703 & -0.23131150 \\ -0.400 & 0.29201394 \\ 0.747 & -0.38575963 \quad\left(^{*}\right) \\ 1.772 & -0.19142061 \\ 4.511 & -0.67185709 \\ -0.947 & 0.00000118 \\ -3.203 & 0.04161093 \\ -0.186 & -0.60323802 \\ -1.840 & 0.77839036 \\ 2.540 & -0.10497520 \\ -1.501 & 0.72849685 \\ -1.962 & 0.68753953\left({ }^{* * *}\right) \\ -10.517 & 1.78878670\end{array}$

gt z-stat
2.633
0.213
-0.023
-2.359
-4.139
-0.684
0.134
3.392
0.422
-2.532
-2.682
4.253
2.397
4.309

$\mathrm{t}$ coeff
0.81645606
$-0.17969241{ }^{*}$
$1.92841191\left(^{*}\right)$
$\left.0.92375841{ }^{* * *}\right)$
$8.29134546\left(^{* * *}\right)$
$-0.59902412\left(^{* * *}\right)$
$0.00001658\left(^{* *}\right)$
$0.08978031\left(^{* *}\right)$
-2.56545285
$-4.79659216\left(^{* * *}\right)$
\left.$-1.88535599{\left({ }^{* *}\right)}^{* * *}\right)$
$-2.45861170\left(^{* * *}\right)$
$-3.68298861\left(^{* * *}\right)$
$-0.82008412\left(^{* *}\right)$

\begin{tabular}{rr} 
t z-stat & \multicolumn{1}{c}{ alpha } \\
-0.377 & -0.00016445 \\
0.525 & 0.00002063 \\
1.142 & -0.00001364 \\
3.444 & 0.00002744 \\
4.544 & 0.00008390 \\
-2.26 & 0.00013296 \\
2.586 & 0.00000000 \\
0.487 & -0.00003320 \\
-2.483 & -0.00001173 \\
-1.184 & -0.00015531 \\
-0.035 & 0.00007869 \\
-4.491 & -0.00012069 \\
0.065 & -0.00004554 \\
-2.939 & -0.00020979
\end{tabular}

Hausman

prob

$\mathrm{y}^{*} \quad$ accept RE

Table 5. BSS Model: Random Effects Estimate 


\section{BSS Cubic Model Fixed Effects Estimates}

Model Specification $\quad \mathrm{P}=$ alpha $\left(\mathrm{y}-\mathrm{y}^{*}\right)\left(\mathrm{y}-\mathrm{y}^{* *}\right) \mathrm{gt}+\mathrm{beta}^{*} \mathrm{t}+($ temperature controls $)+\mathrm{C}$

Implemented as $\quad \mathrm{P}=\mathrm{a} 1 *(\mathrm{y} \wedge 2 \mathrm{gt})+\mathrm{a} 2 *(\mathrm{ygt})+\mathrm{a} 3 *(\mathrm{gt})+\mathrm{a} 4 * \mathrm{t}+($ temperature controls $)+\mathrm{C}$

\begin{tabular}{|c|c|c|c|c|c|c|c|c|}
\hline \multirow[b]{2}{*}{ Pollutant } & \multicolumn{8}{|c|}{ 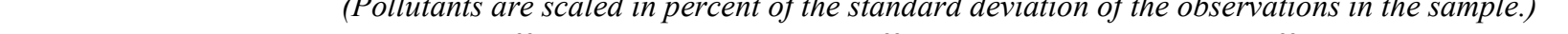 } \\
\hline & y2gt & y2gt z-stat & ygt coeff & ygt z-stat & gt coeff & gt z-stat & t coeff & t z-stat \\
\hline arsenic & $7.90 \mathrm{E}-09$ & 0.464 & $-3.07 \mathrm{E}-02(*)$ & -1.627 & $1.98 \mathrm{E}+02$ & 0.961 & $3.71 \mathrm{E}+00$ & 0.879 \\
\hline BOD & $3.15 \mathrm{E}-08(* *)$ & 2.127 & $-2.51 \mathrm{E}-02(* * *)$ & -2.639 & $8.22 \mathrm{E}+01(*)$ & 1.925 & $-1.17 \mathrm{E}+00$ & -1.234 \\
\hline cadmium & $3.11 \mathrm{E}-08$ & 1.349 & $-3.53 \mathrm{E}-02$ & -1.219 & $1.66 \mathrm{E}+02$ & 0.572 & $7.26 \mathrm{E}+00(*)$ & 1.656 \\
\hline COD & 4.47E-08 (*) & 1.775 & $-3.44 \mathrm{E}-02(* * *)$ & -3.099 & $-1.55 \mathrm{E}+02(* * *)$ & -2.807 & $6.90 \mathrm{E}+00(* * *)$ & 4.586 \\
\hline coliform & $-1.89 \mathrm{E}-08$ & -0.53 & 5.59E-02 $(* * *)$ & 3.624 & $-2.08 \mathrm{E}+02(* *)$ & -2.201 & $6.17 \mathrm{E}+00(* *)$ & 1.965 \\
\hline dissolved O2 & $1.70 \mathrm{E}-08(* *)$ & 1.967 & 7.03E-03 & 1.604 & $-8.59 \mathrm{E}+00$ & -0.419 & $-1.21 \mathrm{E}+00(* *)$ & -1.979 \\
\hline fecal coliform & $-2.91 \mathrm{E}-13(* * *)$ & -4.321 & $1.90 \mathrm{E}-07(* * *)$ & 3.933 & $-4.13 \mathrm{E}-06$ & -0.015 & $1.02 \mathrm{E}-05$ & 1.621 \\
\hline lead & 4.78E-09 (*) & 1.744 & $4.45 \mathrm{E}-03$ & 1.381 & $-8.98 \mathrm{E}+01(* * *)$ & -2.87 & $9.26 \mathrm{E}-03$ & 0.018 \\
\hline mercury & $3.18 \mathrm{E}-08$ & 1.299 & $-1.34 \mathrm{E}-02$ & -0.432 & $1.35 \mathrm{E}+02$ & 0.453 & $-6.07 \mathrm{E}+00$ & -1.353 \\
\hline nickel & 3.39E-08 & 1.347 & $1.56 \mathrm{E}-01(* *)$ & 2.278 & $-2.18 \mathrm{E}+03(* * *)$ & -2.664 & $-3.73 \mathrm{E}+00$ & -0.794 \\
\hline nitrates & $-8.51 \mathrm{E}-09$ & -0.429 & $1.80 \mathrm{E}-02(*)$ & 1.552 & $-1.59 \mathrm{E}+02(* * *)$ & -2.798 & 8.09E-02 & 0.057 \\
\hline smoke & $-8.93 \mathrm{E}-09$ & -1.116 & $-2.52 \mathrm{E}-02(*)$ & -1.955 & $3.71 \mathrm{E}+02(* * *)$ & 3.52 & $-4.14 \mathrm{E}+00(* * *)$ & -4.629 \\
\hline so 2 & $3.65 \mathrm{E}-08(* * *)$ & 5.607 & $-5.60 \mathrm{E}-02(* * *)$ & -9.496 & $1.06 \mathrm{E}+02(* * *)$ & 2.714 & $1.09 \mathrm{E}+00$ & 1.233 \\
\hline suspended particles & $-2.89 \mathrm{E}-10$ & -0.058 & $-3.46 \mathrm{E}-03$ & -0.778 & $1.03 \mathrm{E}+02(* * *)$ & 4.259 & $-2.31 \mathrm{E}+00(* * *)$ & -2.937 \\
\hline
\end{tabular}

\begin{tabular}{rrr} 
alpha & \multicolumn{1}{c}{$\mathrm{y}^{*}$} & \multicolumn{1}{c}{$\mathrm{y}^{* *}$} \\
$7.90 \mathrm{E}-09$ & 6442 & 3880419 \\
$3.15 \mathrm{E}-08$ & 3286 & 794499 \\
$3.11 \mathrm{E}-08$ & 4729 & 1129371 \\
$4.47 \mathrm{E}-08$ & -4469 & 774123 \\
$-1.89 \mathrm{E}-08$ & 3725 & 2956411 \\
$1.70 \mathrm{E}-08$ & -416068 & 1218 \\
$-2.91 \mathrm{E}-13$ & 22 & 653289 \\
$4.78 \mathrm{E}-09$ & -949998 & 19766 \\
$3.18 \mathrm{E}-08$ & 10341 & 410260 \\
$3.39 \mathrm{E}-08$ & -4625173 & 13913 \\
$-8.51 \mathrm{E}-09$ & 8875 & 2110825 \\
$-8.93 \mathrm{E}-09$ & -2831988 & 14682 \\
$3.65 \mathrm{E}-08$ & 1891 & 1531250 \\
$-2.89 \mathrm{E}-10$ & -11999007 & 29652
\end{tabular}

Table 6. BSS Cubic Model: Fixed Effects Estimates 
Model Specification Implemented as

$?$

\section{BSS Cubic Model}

\section{Random Effects Estimates}

(Pollutants are scaled in percent of the standard deviation of the observations in the sample.)

\begin{tabular}{ll}
\multicolumn{1}{c}{ Pollutant } & y2gt \\
arsenic & $-1.64 \mathrm{E}-08\left(^{* * *}\right)$ \\
BOD & $-2.34 \mathrm{E}-09$ \\
cadmium & $-8.58 \mathrm{E}-09$ \\
COD & $-3.35 \mathrm{E}-09$ \\
coliform & $1.46 \mathrm{E}-08$ \\
dissolved O2 & $2.73 \mathrm{E}-08\left(^{* * *}\right)$ \\
fecal coliform & $-1.22 \mathrm{E}-13\left(^{* * *}\right)$ \\
lead & $7.60 \mathrm{E}-10$ \\
mercury & $8.48 \mathrm{E}-09$ \\
nickel & $-1.51 \mathrm{E}-08$ \\
nitrates & $-1.46 \mathrm{E}-08\left(^{* * *}\right)$ \\
smoke & $-6.94 \mathrm{E}-09$ \\
so2 & $-1.32 \mathrm{E}-08\left(^{* * *}\right)$ \\
suspended particles & $9.63 \mathrm{E}-10$
\end{tabular}

\begin{tabular}{|c|c|c|c|c|c|c|}
\hline gt Z-stat & $t$ coeff & t z-stat & alpha & $y^{*}$ & $\mathrm{y}^{* *}$ & $\begin{array}{l}\text { Hausman } \\
\text { prob } \\
\text { accept RE }\end{array}$ \\
\hline-0.21 & $2.90 \mathrm{E}+00\left({ }^{* *}\right)$ & 2.019 & $-1.64 \mathrm{E}-08$ & imaginary & imaginary & 0.4781 \\
\hline-1.173 & $-7.81 \mathrm{E}-01$ & -1.202 & $-2.34 \mathrm{E}-09$ & 8597 & 14217 & 0.1427 \\
\hline-0.323 & $4.16 \mathrm{E}+00\left(^{* * *}\right)$ & 2.77 & $-8.58 \mathrm{E}-09$ & 1266 & 13178 & 0.019 \\
\hline-1.549 & $1.27 \mathrm{E}+00\left(^{*}\right)$ & 1.727 & $-3.35 \mathrm{E}-09$ & imaginary & imaginary & 0.0001 \\
\hline 0.494 & $6.05 \mathrm{E}+00\left(^{* * *}\right)$ & 5.571 & $1.46 \mathrm{E}-08$ & imaginary & imaginary & \\
\hline-0.233 & $-1.13 \mathrm{E}+00\left(^{* * *}\right)$ & -3.8 & $2.73 \mathrm{E}-08$ & -272 & 7545 & \\
\hline-1.518 & 2.32E-05 $\left({ }^{* *}\right)$ & 5.511 & $-1.22 \mathrm{E}-13$ & 2007 & 9491 & \\
\hline 0.181 & $-3.70 \mathrm{E}-01$ & -1.579 & $7.60 \mathrm{E}-10$ & 495 & 53652 & 0.0032 \\
\hline-0.134 & $-3.60 \mathrm{E}+00\left({ }^{* *}\right)$ & -1.97 & $8.48 \mathrm{E}-09$ & -718 & 17438 & 0.5455 \\
\hline-0.691 & $-3.53 \mathrm{E}+00$ & -1.998 & $-1.51 \mathrm{E}-08$ & imaginary & imaginary & 0.0494 \\
\hline-1.809 & $-1.58 \mathrm{E}+00\left(^{*}\right)$ & -1.886 & $-1.46 \mathrm{E}-08$ & 2087 & 16345 & 0.0044 \\
\hline 0.667 & $-2.12 \mathrm{E}+00\left(^{* * *}\right)$ & -3.299 & $-6.94 \mathrm{E}-09$ & -11178 & 6246 & 0.0001 \\
\hline 1.393 & $-2.54 \mathrm{E}+00\left(^{* * *}\right)$ & -4.437 & $-1.32 \mathrm{E}-08$ & -1799 & 11429 & \\
\hline 8.479 & $-9.06 \mathrm{E}-01\left(^{*}\right)$ & -1.936 & $9.63 \mathrm{E}-10$ & 8406 & 224094 & \\
\hline
\end{tabular}

ausman

pept RE

0.1427

0.019

0001

$1.264-1.43 \mathrm{E}-01$

$0.569-4.50 \mathrm{E}-01$

$-0.568 \quad 2.06 \mathrm{E}-01$

$-3.095-5.60 \mathrm{E}-02$

$3.279-2.33 \mathrm{E}-06$

$-1.775 \quad 2.02 \mathrm{E}-02$

$-0.804-1.06 \mathrm{E}-01$

$0.705-1.08 \mathrm{E}+00$

$3.267 \quad-4.99 \mathrm{E}-01\left(^{*}\right)$

$\begin{array}{ll}0.337 & 4.84 \mathrm{E}-01 \\ 2.691 & 2.72 \mathrm{E}-01\end{array}$

$-4.627 \quad 1.81 \mathrm{E}+00(* * *)$

$8.479-9.06 \mathrm{E}-01\left(^{*}\right)$

$-1.936 \quad 9.63 \mathrm{E}-10$

$8406 \quad 224094$

Table 7. BSS Cubic Model: Random Effects Estimates 


\section{Environmental Kuznets Curve Evidence from}

the

Coefficients*

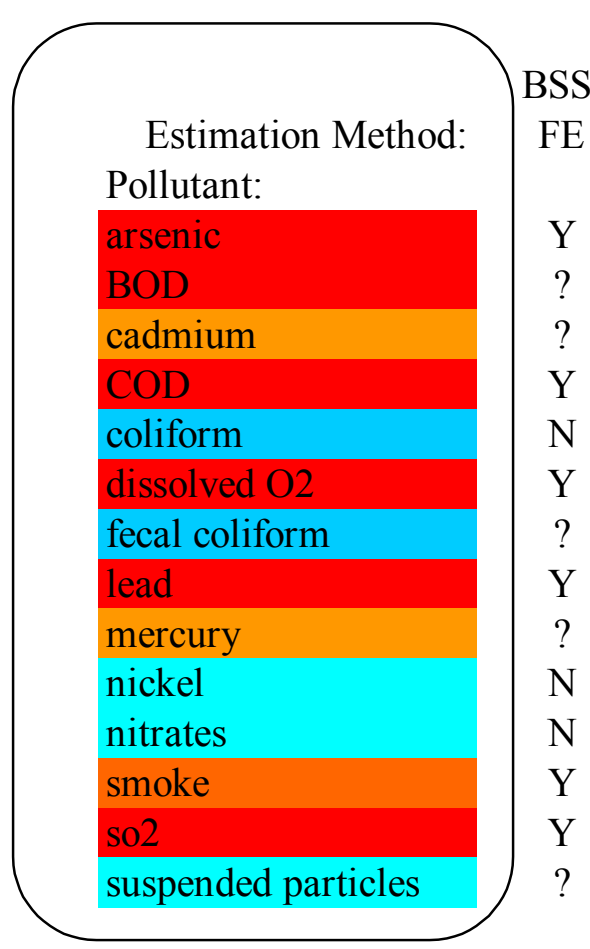

BSS
Cubic
FE

$?$
$\mathrm{Y}$
$?$
$\mathrm{Y}$
$?$
$\mathrm{Y}$
$\mathrm{N}$
$\mathrm{Y}$
$?$
$?$
$?$
$?$
$\mathrm{Y}$
$?$

\section{Interpreting the \\ Charts**}

Model

\begin{tabular}{ccc}
\multicolumn{3}{c}{ BSS } \\
BSS & Cubic & GK \\
FE & FE & RE \\
& & \\
Y & Y & YN \\
Y & Y & Y \\
N & Y & Y \\
Y & Y & Y \\
NN & NN & N \\
Y & Y & Y \\
N & N & Y \\
Y & N & YN \\
N & Y & YN \\
NN & N & YN \\
NN & NN & Y \\
Y & N & YN \\
Y & Y & YN \\
N & N & Y
\end{tabular}

Score

4.5

4.5

3.0

5.0

0.5

5.0

1.5

4.0

3.0

1.5

1.5

3.5

5.0

2.0

* Y means the key coefficient is significant at at least the $10 \%$ level and of the right sign; $\mathrm{N}$ means significant and of the wrong sign; ? means insignificant.

** For the charts, $\mathrm{Y}=$ graphs start positive, end negative; $\mathrm{NN}=$ graphs start negative and end positive; $\mathrm{N}=$ graphs don't clearly or monotonically move up or down; $\mathrm{YN}=$ graphs start positive, go negative, then go positive again.

Source: Author's calculations and Grossman and Krueger (1995); see text.

Table 8. Interpreting the Evidence for the Environmental Kuznets Curve 


\section{Figures}

Arsenic:

\begin{tabular}{lllll}
\multicolumn{2}{c}{ Slopes } & & & \\
& $\mathrm{L}$ & $\mathrm{M}$ & $\mathrm{H}$ & $\mathrm{VH}$ \\
BSS & 0.03357 & 0.02260 & 0.00890 & -0.01851 \\
cubic & 0.01669 & 0.00442 & -0.01089 & -0.04137 \\
GK & 0.00473 & -0.00045 & -0.02090 & 0.14671
\end{tabular}

$\begin{array}{cccc}\text { Error bars } & & & \\ L & M & H & \text { VH } \\ 0.02558 & 0.020872 & 0.018104 & 0.025758 \\ 0.039567 & 0.040027 & 0.047541 & 0.074821 \\ 0.001761 & 0.002033 & 0.003463 & 0.072184\end{array}$

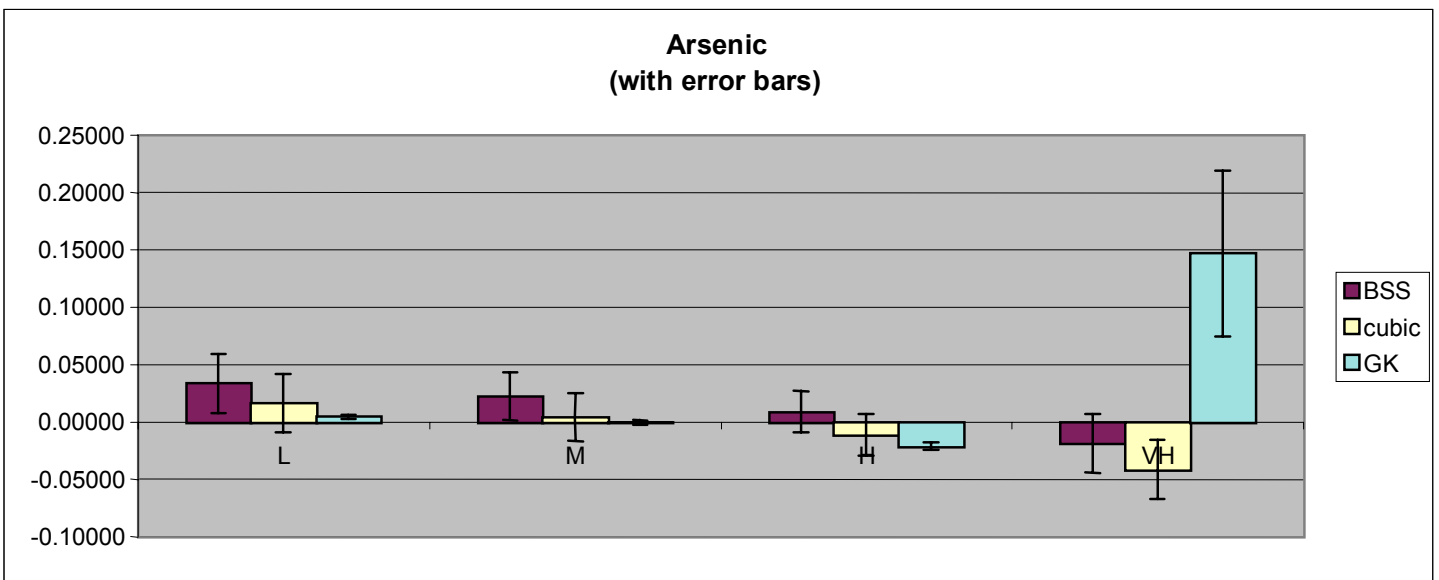

BOD

Figure 2. Arsenic

\begin{tabular}{|c|c|c|c|c|c|c|c|c|}
\hline \multicolumn{3}{|c|}{ Slopes } & \multicolumn{6}{|c|}{ Error bars } \\
\hline & L & $\mathrm{M}$ & $\mathrm{H}$ & VH & L & $M$ & $\mathrm{H}$ & VH \\
\hline BSS & 0.0000916 & -0.0025656 & -0.0058871 & -0.0125300 & 0.0065423 & 0.0058011 & 0.0071996 & 0.0136721 \\
\hline cubic & 0.0057124 & -0.0042619 & -0.0165880 & -0.0407679 & 0.0081151 & 0.0108710 & 0.0183663 & 0.0357184 \\
\hline GK & 0.0006769 & 0.0013177 & -0.0022337 & -0.0219535 & 0.0006482 & 0.0010812 & 0.0024302 & 0.0553990 \\
\hline
\end{tabular}

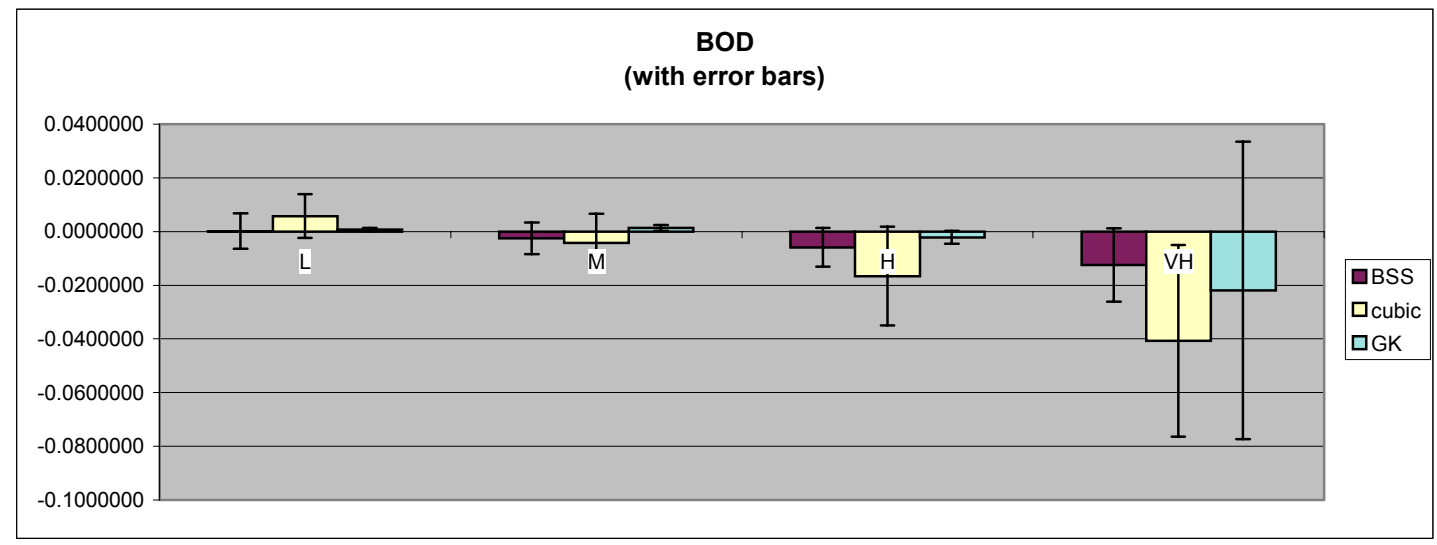

Figure 3. Biological Oxygen Demand 


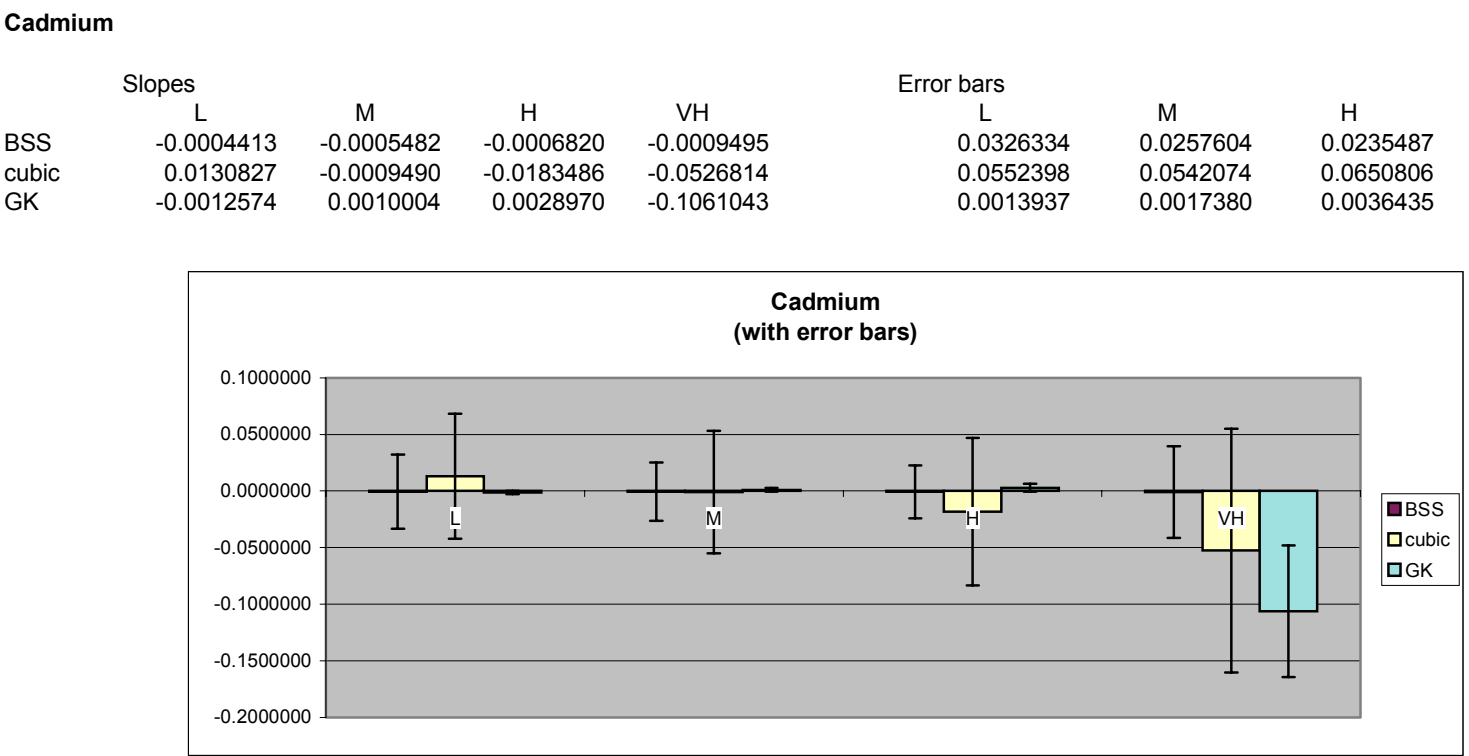

Figure 4. Cadmium

COD

\begin{tabular}{|c|c|c|c|c|}
\hline \multicolumn{5}{|c|}{ Slopes } \\
\hline & L & M & $\mathrm{H}$ & $\mathrm{VH}$ \\
\hline & -0.01267 & -0.01753 & -0.02361 & -0.03576 \\
\hline & -0.01891 & -0.03257 & -0.04945 & -0.08253 \\
\hline & 0.00082 & 0.001902 & -0.00291 & -0.04085 \\
\hline
\end{tabular}

Error bars

$\begin{array}{cccc}\mathrm{L} & \mathrm{M} & \mathrm{H} & \mathrm{VH} \\ 0.009353 & 0.010469 & 0.014666 & 0.026182 \\ 0.010772 & 0.014399 & 0.023019 & 0.043018 \\ 0.000754 & 0.001249 & 0.003094 & 0.065809\end{array}$

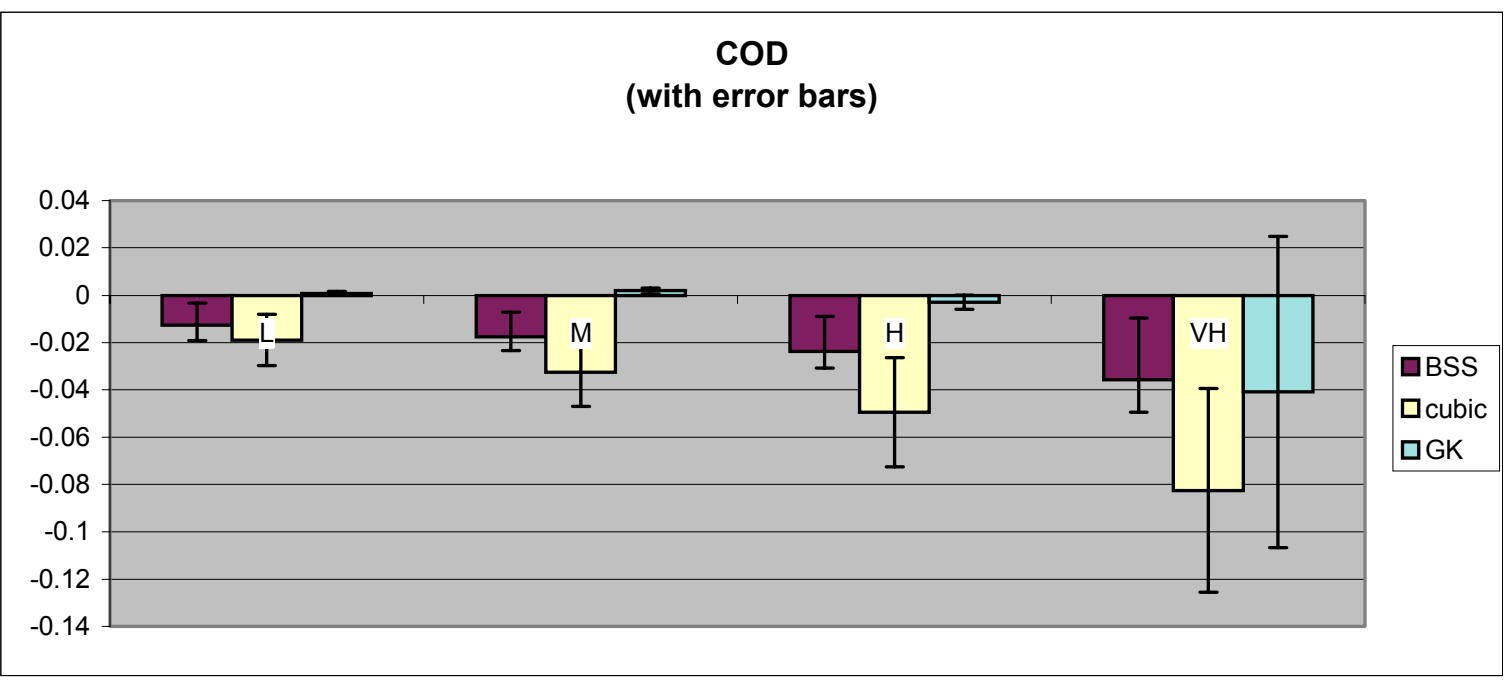

Figure 5. Chemical Oxygen Demand 


\section{Coliform}

\begin{tabular}{lrrrr}
\multicolumn{4}{c}{ Slopes } & \multicolumn{3}{c}{} \\
& $\mathrm{L}$ & $\mathrm{M}$ & $\mathrm{H}$ & \multicolumn{1}{c}{ VH } \\
BSS & -0.029909499 & -0.014954332 & 0.003739628 & 0.04112755 \\
cubic & -0.015198309 & 0.007098507 & 0.034884615 & 0.0901738 \\
GK & 0.003957005 & -0.007928295 & 0.033815354 & 1.05935347
\end{tabular}

$\begin{array}{cccc}\begin{array}{c}\text { Error bars } \\ \mathrm{L}\end{array} & \mathrm{M} & \mathrm{H} & \mathrm{VH} \\ 0.01629305 & 0.01911795 & 0.02473873 & 0.03885763 \\ 0.0190347 & 0.02493802 & 0.03669513 & 0.06396293 \\ 0.00136245 & 0.00393835 & 0.0100038 & 0.34462411\end{array}$

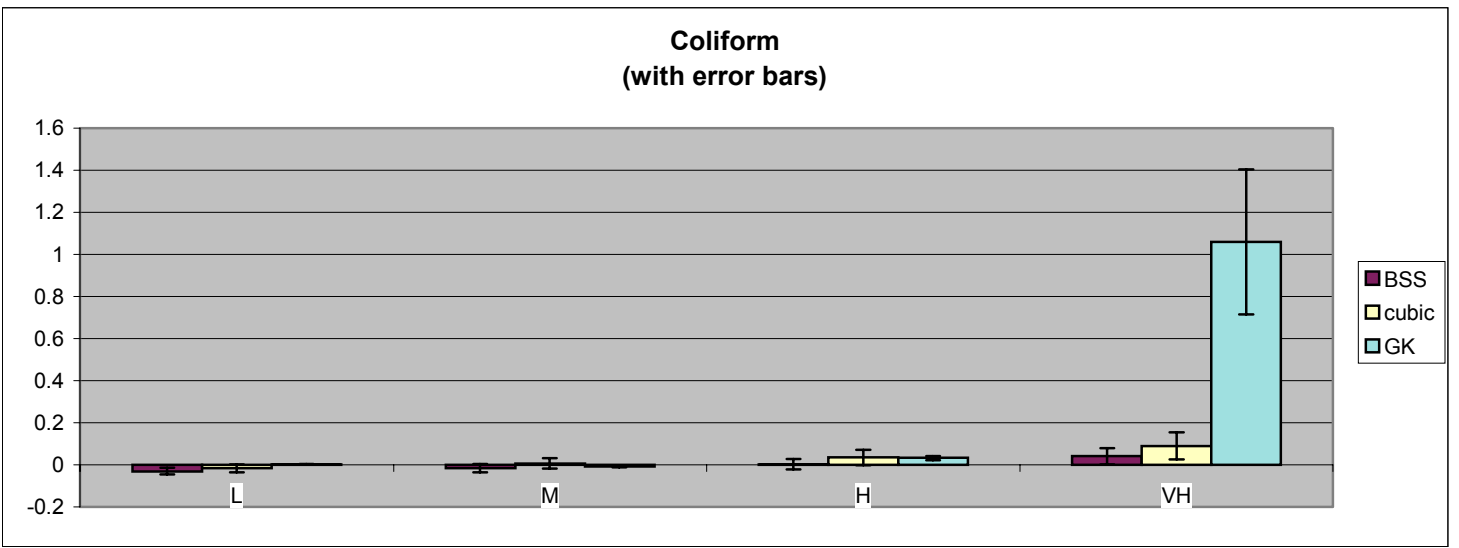

Figure 6. Coliform

\section{DisO2}

\begin{tabular}{|c|c|c|c|c|c|c|c|c|}
\hline \multicolumn{3}{|c|}{ Slopes } & \multicolumn{6}{|c|}{ Error bars } \\
\hline & L & $\mathrm{M}$ & $\mathrm{H}$ & $\mathrm{VH}$ & L & M & $\mathrm{H}$ & $\mathrm{VH}$ \\
\hline $3 S S$ & -0.000194662 & 0.003842916 & $0.00888988 \mathrm{~s}$ & 0.018984 & 0.003458 & 0.0041 & 0.005771 & 0.010054 \\
\hline ubic & -0.000154395 & 0.002699698 & 0.006343608 & 0.013886 & 0.003994 & 0.005461 & 0.008928 & 0.01688 \\
\hline 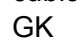 & $-5.35715 \mathrm{E}-05$ & 0.00085653 & 0.00758786 & 0.059101 & 0.000761 & 0.001262 & 0.002691 & 0.051897 \\
\hline
\end{tabular}

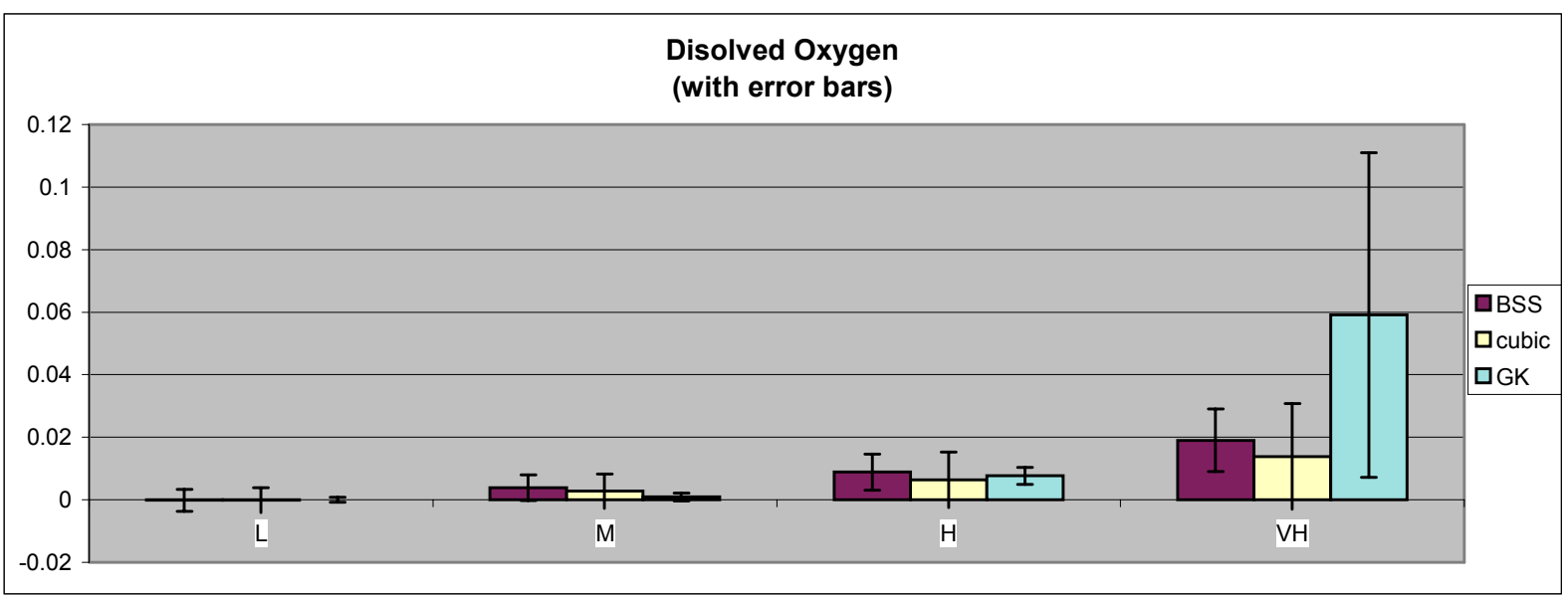

Figure 7. Dissolved Oxygen 
Fecal coliform

\begin{tabular}{lrccc}
\multicolumn{2}{c}{ Slopes } & \multicolumn{3}{l}{} \\
& $\mathrm{L}$ & $\mathrm{M}$ & $\mathrm{H}$ & $\mathrm{VH}$ \\
BSS & $5.75632 \mathrm{E}-09$ & $1.59298 \mathrm{E}-08$ & $2.86467 \mathrm{E}-08$ & $5.41 \mathrm{E}-08$ \\
cubic & $1.8551 \mathrm{E}-08$ & $9.38272 \mathrm{E}-08$ & $1.86614 \mathrm{E}-07$ & $3.68 \mathrm{E}-07$ \\
GK & $5.74078 \mathrm{E}-10$ & $1.19182 \mathrm{E}-08$ & $-2.96828 \mathrm{E}-08$ & $-7.8 \mathrm{E}-07$
\end{tabular}

\begin{tabular}{crcc}
$\begin{array}{c}\text { Error bars } \\
\mathrm{L}\end{array}$ & \multicolumn{1}{c}{$\mathrm{M}$} & $\mathrm{H}$ & $\mathrm{VH}$ \\
$4.43 \mathrm{E}-08$ & $3.94 \mathrm{E}-08$ & $4.68 \mathrm{E}-08$ & $8.56 \mathrm{E}-08$ \\
$5.34 \mathrm{E}-08$ & $6.4 \mathrm{E}-08$ & $9.81 \mathrm{E}-08$ & $1.83 \mathrm{E}-07$ \\
$3.89 \mathrm{E}-09$ & $6.55 \mathrm{E}-09$ & $1.45 \mathrm{E}-08$ & $2.55 \mathrm{E}-07$
\end{tabular}

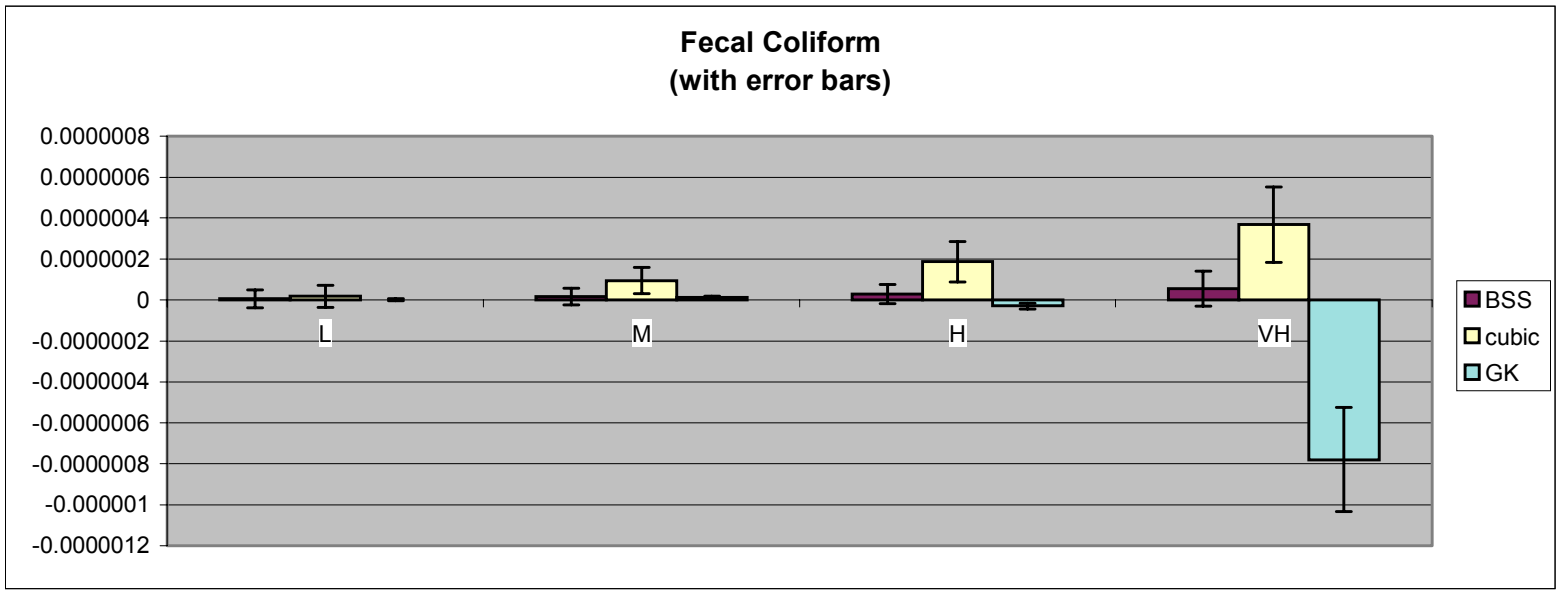

Figure 8. Fecal Coliform

Lead

\begin{tabular}{|c|c|c|c|c|}
\hline \multicolumn{5}{|c|}{ Slopes } \\
\hline & $\mathrm{L}$ & M & $\mathrm{H}$ & VH \\
\hline BSS & 0.009845665 & 0.00560676 & 0.000308128 & -0.01029 \\
\hline cubic & -0.008530182 & -0.006740148 & -0.004481097 & 0.000109 \\
\hline GK & 7.40852E-05 & -0.001077859 & -0.002426865 & 0.016392 \\
\hline
\end{tabular}

\begin{tabular}{cccr} 
Error bars & & & \\
$L$ & $M$ & $H$ & \multicolumn{1}{c}{ VH } \\
0.005929 & 0.004765 & 0.004495 & 0.007662 \\
0.005961 & 0.005946 & 0.007283 & 0.01215 \\
0.000338 & 0.000438 & 0.000834 & 0.014555
\end{tabular}

Lead

(with error bars)

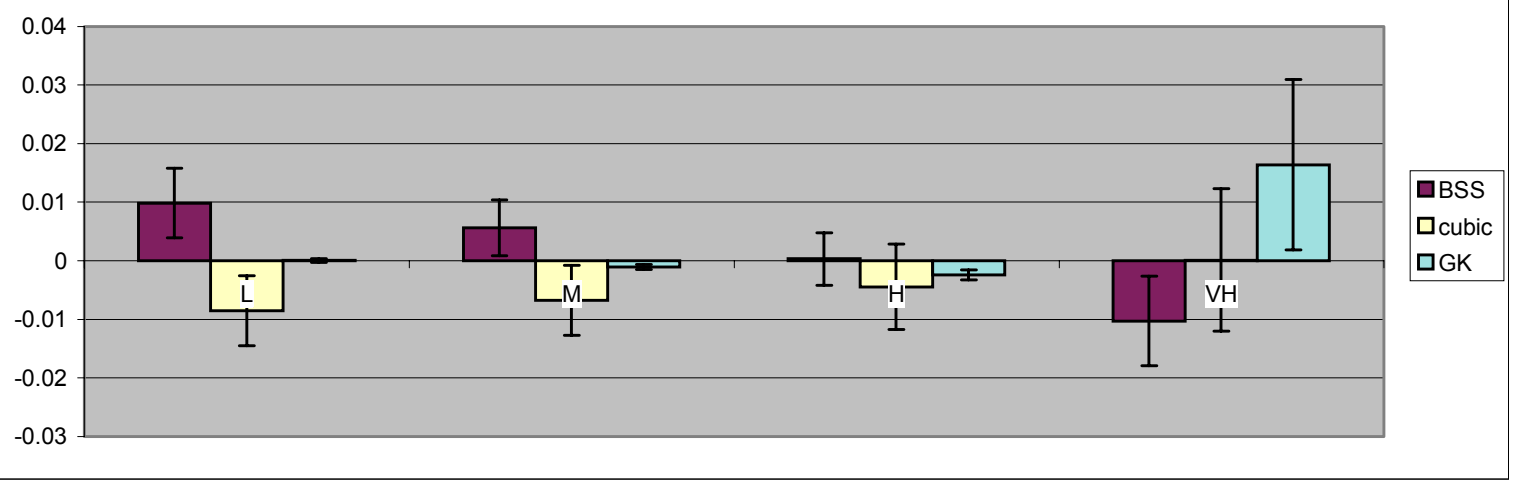

Figure 9. Lead 


\section{Mercury}

\begin{tabular}{lcccc}
\multicolumn{5}{c}{ Slopes } \\
L & M & H & VH \\
BSS & 0.009493 & 0.01419 & 0.020062 & 0.031805 \\
cubic & 0.012149 & 0.006879 & 0.000434 & -0.01198 \\
GK & 0.003025 & $-8.3 E-05$ & -0.00755 & 0.159621
\end{tabular}

Error bars

\begin{tabular}{ccrc}
$L$ & $M$ & \multicolumn{1}{c}{$H$} & VH \\
0.0359971 & 0.0269086 & 0.0228904 & 0.04288274 \\
0.0565416 & 0.0556784 & 0.067986 & 0.11446133 \\
0.0057809 & 0.0167106 & 0.0424465 & 1.46225405
\end{tabular}

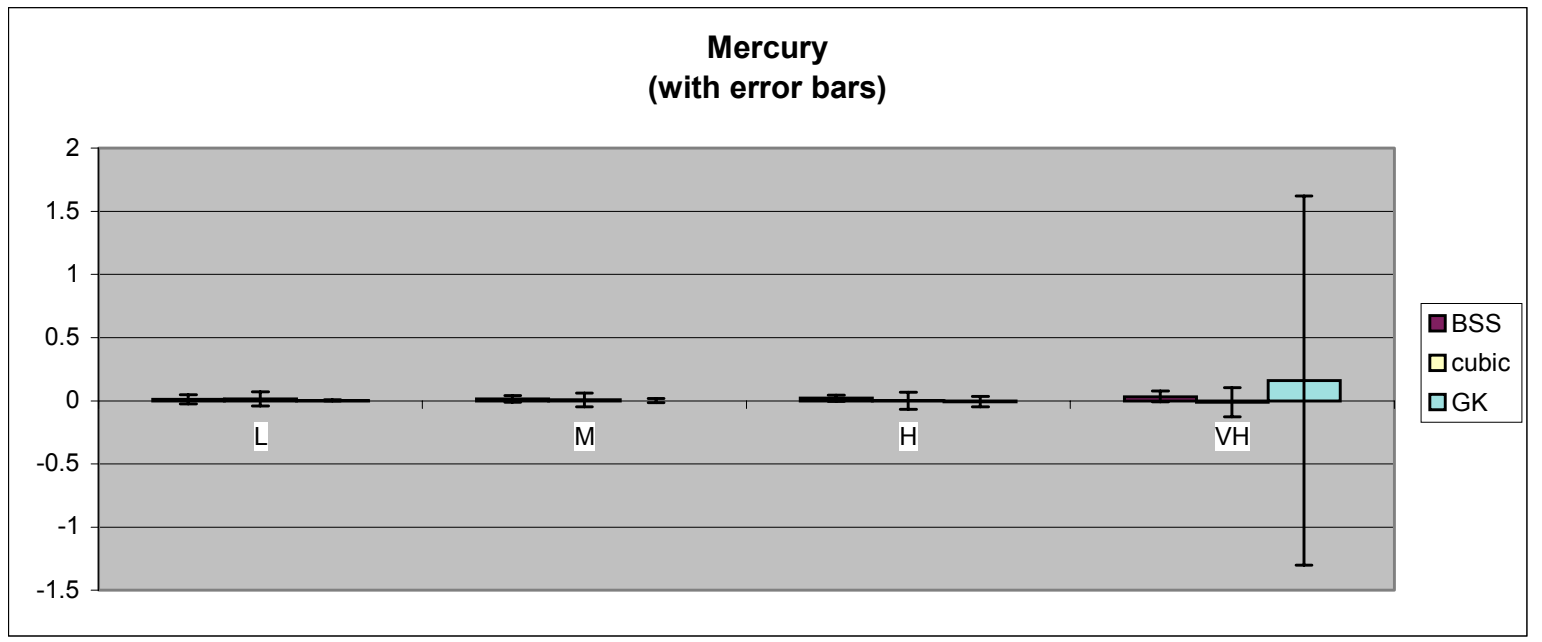

\section{Nickel}

Figure 10. Mercury

\begin{tabular}{|c|c|c|c|c|c|c|c|c|}
\hline \multicolumn{3}{|c|}{ Slopes } & \multicolumn{6}{|c|}{ Error bars } \\
\hline & L & $\mathrm{M}$ & $\mathrm{H}$ & VH & L & M & $\mathrm{H}$ & VH \\
\hline BSS & -0.18599 & -0.12205 & -0.04212 & 0.117733 & 0.143437 & 0.092776 & 0.040439 & 0.119633 \\
\hline cubic & -0.20238 & -0.13981 & -0.06145 & 0.095794 & 0.154507 & 0.141584 & 0.153059 & 0.239586 \\
\hline GK & 0.001359 & -0.00111 & -0.00925 & 0.038387 & 0.004258 & 0.004754 & 0.003438 & 0.125988 \\
\hline
\end{tabular}

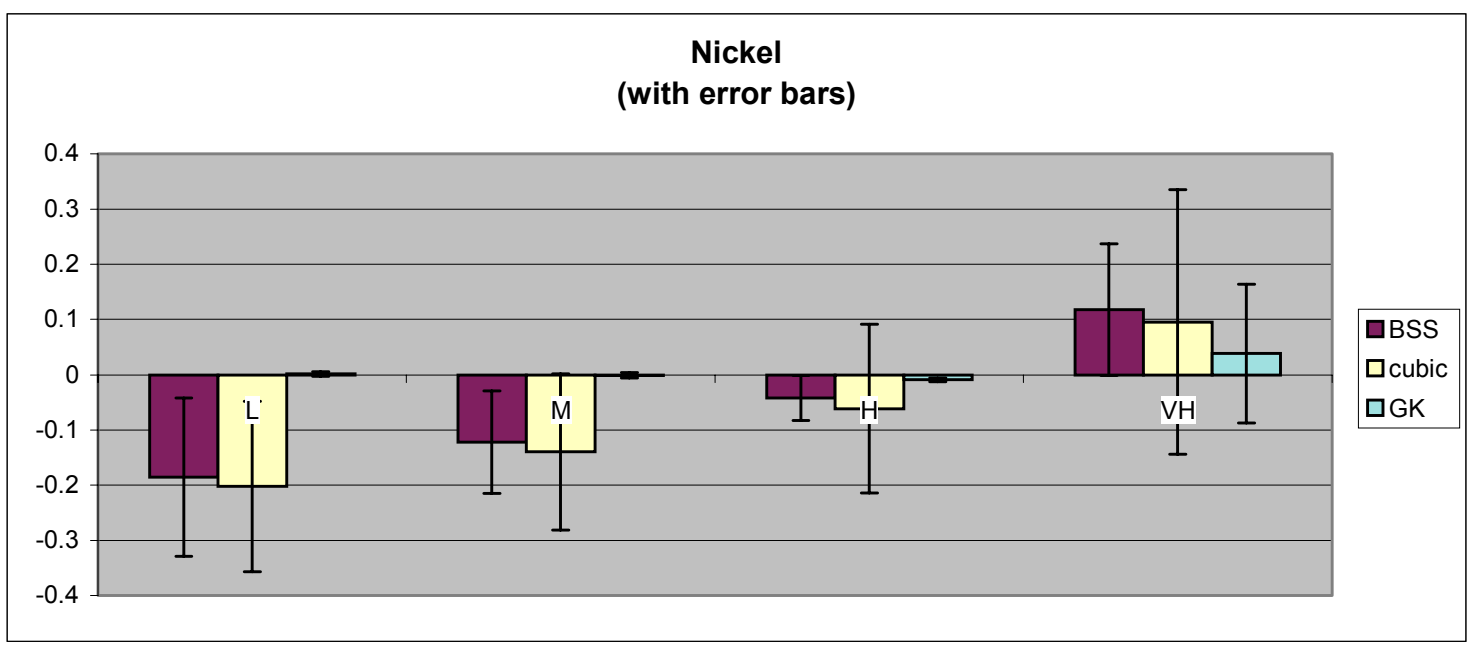

Figure 11. Nickel 
Nitrates

\begin{tabular}{lccrc}
\multicolumn{4}{c}{ Slopes } & \multicolumn{3}{c}{} \\
& $\mathrm{L}$ & $\mathrm{M}$ & $\mathrm{H}$ & $\mathrm{VH}$ \\
BSS & -0.012417442 & -0.00722839 & -0.000742076 & 0.01223055 \\
cubic & -0.014132824 & -0.006941508 & 0.002009362 & 0.01978352 \\
GK & -0.000336574 & 0.005123009 & 0.002625 & -0.1894721
\end{tabular}

Error bars

$\begin{array}{lllll}\text { L } & M & H & \text { VH }\end{array}$

$\begin{array}{llll}0.00966026 & 0.00978117 & 0.01295492 & 0.02329986\end{array}$

$\begin{array}{lllll}0.01094586 & 0.01426961 & 0.02317559 & 0.04412702\end{array}$

$\begin{array}{lllll}0.00069625 & 0.00117284 & 0.00247519 & 0.05085072\end{array}$

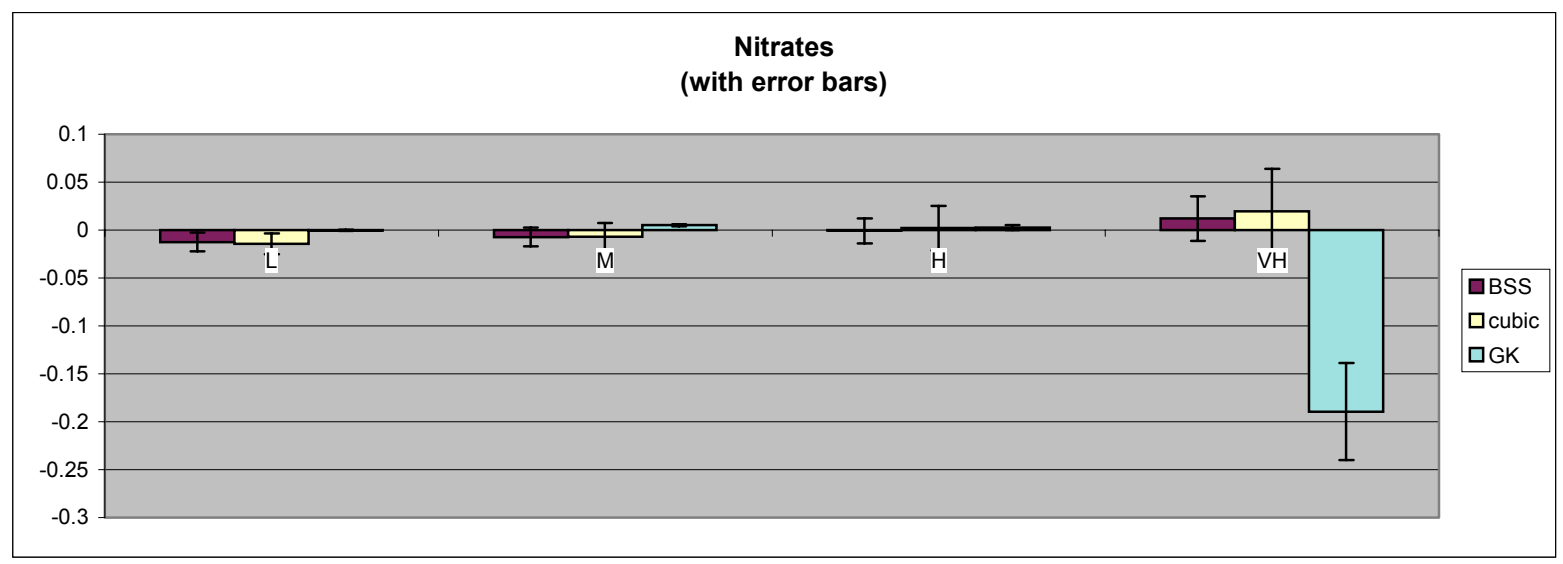

Figure 12. Nitrates

Smoke

\begin{tabular}{lrrrr}
\multicolumn{5}{c}{ Slopes } \\
L & M & $H$ & \multicolumn{1}{c}{ VH } \\
BSS & 0.0380922 & 0.02420601 & 0.00684827 & -0.0278672 \\
cubic & 0.03461147 & 0.0245274 & 0.01188213 & -0.01354234 \\
GK & 0.00541896 & 0.00407772 & -0.0104472 & 0.16429572
\end{tabular}

Error bars

$\begin{array}{cccc}\mathrm{L} & \mathrm{M} & \mathrm{H} & \mathrm{VH} \\ 0.01746513 & 0.01131428 & 0.00809789 & 0.02168299 \\ 0.0196971 & 0.01890954 & 0.02458803 & 0.04518124 \\ 0.00177781 & 0.00174022 & 0.00613318 & 0.20091071\end{array}$

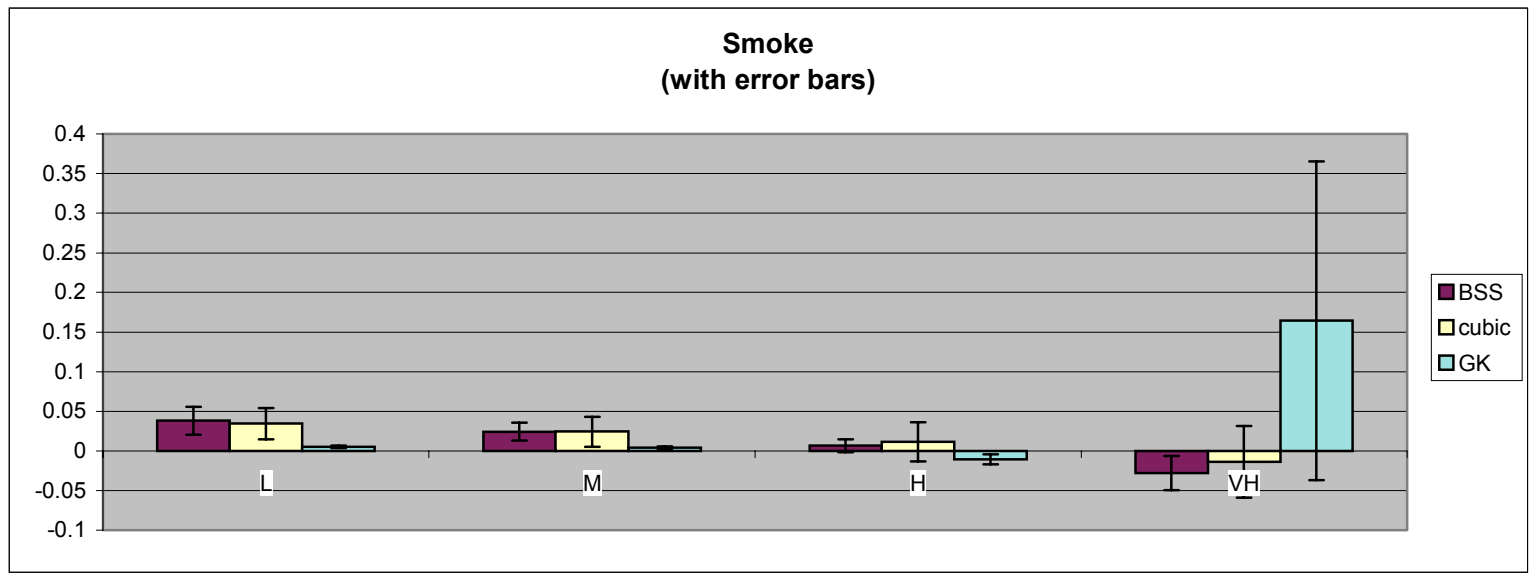

Figure 13. Smoke 


\section{Sulphur Dioxide}

\begin{tabular}{lcccc}
\multicolumn{5}{c}{ Slopes } \\
L & M & H & VH \\
BSS & 0.006364 & -0.00602 & -0.02151 & -0.05247 \\
cubic & 0.004981 & -0.01734 & -0.04507 & -0.09999 \\
GK & 0.002379 & -0.00251 & -0.01339 & 0.123991
\end{tabular}

\begin{tabular}{ccrc}
$\begin{array}{c}\text { Error bars } \\
\mathrm{L}\end{array}$ & $\mathrm{M}$ & \multicolumn{1}{c}{$\mathrm{H}$} & $\mathrm{VH}$ \\
0.007341 & 0.006462 & 0.007274 & 0.012766 \\
0.007495 & 0.008605 & 0.01248 & 0.022674 \\
0.000592 & 0.000838 & 0.001946 & 0.032552
\end{tabular}

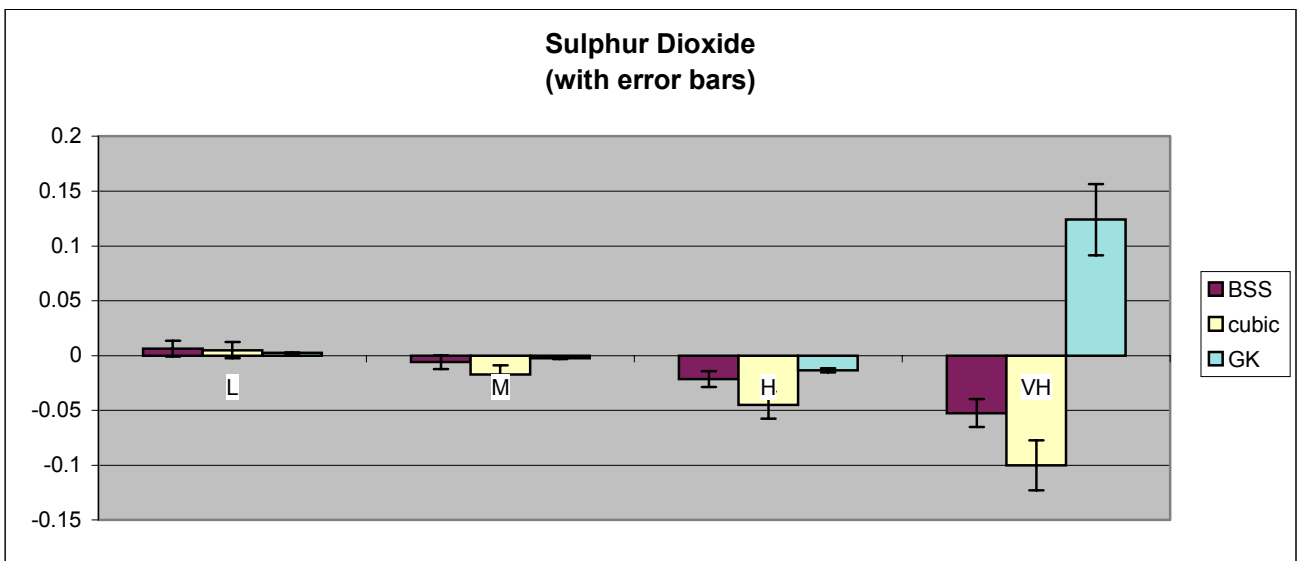

Figure 14. Sulphur Dioxide

\section{Suspended Particles}

\begin{tabular}{|c|c|c|c|c|}
\hline \multicolumn{5}{|c|}{ Slopes } \\
\hline & L & M & $\mathrm{H}$ & $\mathrm{VH}$ \\
\hline & 0.00993868 & 0.00848178 & 0.00666066 & 0.00301841 \\
\hline & & 0.00855344 & 0.00682145 & 0.00335312 \\
\hline & -0.00281062 & -0.00642937 & -0.00411498 & -0.0420257 \\
\hline
\end{tabular}

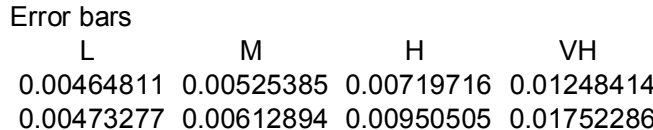
$\begin{array}{llllll}0.00473277 & 0.00612894 & 0.00950505 & 0.01752286\end{array}$ $\begin{array}{lllll}0.0005279 & 0.00071401 & 0.00174005 & 0.02523966\end{array}$

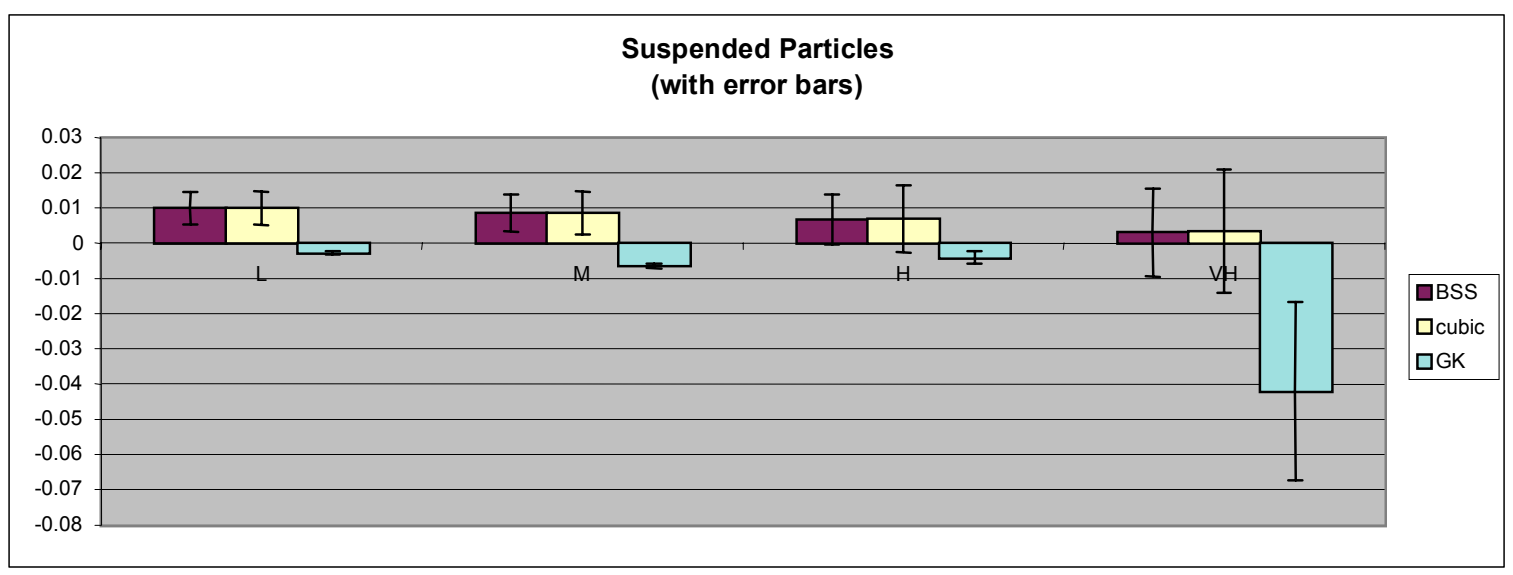

Figure 15. Suspended Particles 